\title{
Global distribution patterns of genera occurring in the Arctic Ocean deeper $2000 \mathrm{~m}$
}

\author{
A.N. Mironov, A.B. Dilman, E.M. Krylova \\ P.P. Shirshov Institute of Oceanology, Russian Academy of Sciences, Nakhimovsky Pr., 36, \\ Moscow, 117997,Russia; e-mail: miron@ocean.ru
}

ABSTRACT: A list of genera represented in the abyssal $(>2000 \mathrm{~m})$ of the Arctic Ocean was compiled for 8 classes (Scaphopoda, Bivalvia, Crinoidea, Echinoidea, Holothuroidea, Asteroidea, Ophiuroidea and Ascidiacea) and some orders from the classes Anthozoa, Maxillopoda and Malacostraca. This list includes 92 genera and 133 species. Species endemic to the Arctic Ocean comprise 51\% whereas species endemic to the Arctic abyssal comprise $19 \%$. Only two small genera are endemic to the Arctic Ocean. Genera with a worldwide distribution (60 genera or 65\%) dominate the Arctic abyssal fauna. Most genera ( 55 or $60 \%$ ) can be considered as deep-sea specialists, with half or more of the species in each genus occurring deeper than $2000 \mathrm{~m}$. About one third of genera (37\%) are known outside the Arctic in the hadal zone $(>6000 \mathrm{~m})$. The share of genera known from the hadal is probably higher in the Arctic abyssal than in the abyssal of other oceans. For many genera, the worldwide minimum or maximum of their depth ranges is found in the Arctic Ocean. Distribution patterns of genera suggest that many deep-sea Arctic species derive from their congeners distributed in geographically distant regions (primarily the Southern Ocean and the Indo-West Pacific). The deep-sea North Atlantic was the main transit region on the pathway to the Arctic. There is no firm evidence of the presence of derivatives of the prePliocene deep-sea Arctic fauna in the modern Arctic fauna. Twelve genera (13\%) with a worldwide distribution are recognized as the most reliable examples of the emergence of the abyssal fauna in the Arctic Ocean. Two genera (2\%) are characterized by the following distribution and ecological patterns: (1) distribution is limited to the Northern Hemisphere, (2) wide bathymetrical range (from shelf to abyssal), (3) abyssal records only within the Arctic Ocean, and (4) very wide ranges of habitats. Arctic submergence of the shelf fauna to the abyssal zone is suggested for these genera. Some higher taxa, not considered in the present work in detail, may have a high share of genera with similar distribution patterns. For instance the share of genera having submerged from the Arctic shelf to the abyssal is about $25 \%$ in the abyssal Arctic amphipod fauna.

KEY WORDS: distribution patterns, genera, Arctic Ocean, abyssal, faunal submergence, faunal emergence.

\section{Особенности глобального распространения родов, обитающих в Северном Ледовитом океане на глубинах более 2000 м}

\author{
А.Н. Миронов, А.Б. Дильман, Е.М. Крылова
}

Институт океанологии им. П.П. Шириова РАН, Нахимовский проспект 36, Москва, 117997, Poccuя; e-mail: miron@ocean.ru 
РЕЗЮМЕ: Список родов, представленных в абиссали (>2000 м) Северного Ледовитого океана составлен для 8 классов (Scaphopoda, Bivalvia, Crinoidea, Echinoidea, Holothuroidea, Asteroidea, Ophiuroidea и Ascidiacea) и некоторых отрядов, принадлежащих к классам Anthozoa, Maxillopoda и Malacostraca. Этот список включает 92 рода и 133 вида. Эндемичные для Северного Ледовитого океана виды составляют $51 \%$, в то время как виды, эндемичные для арктической абиссали, составляют $19 \%$. Только два мелких рода являются эндемиками Северного Ледовитого океана. В арктической абиссальной фауне доминируют роды, широко распространенные в Мировом океане (60 родов или 65\%). Большинство родов (55 или $60 \%$ ) можно также охарактеризовать как преимущественно глубоководные, то есть половина или более половины видов в каждом роду известны на глубинах более 2000 м. Приблизительно треть родов (37\%) известна за пределами Арктического океана в хадальной зоне (>6000 м). Доля родов, известных из хадали, вероятно более высокая в арктической абиссали, чем в абиссали других океанов. Для многих родов самое мелководное или самое глубоководное нахождения сделаны в Северном Ледовитом океане. Особенности распространения родов показывают, что многие глубоководные арктические виды произошли от видов, обитавших в географически отдаленных районах (в первую очередь, в Южном океане и Индо-Вест Пацифике). Глубоководная северная Атлантика сыграла роль основного транзитного региона. Отсутствуют надежные свидетельства о существовании в современном Северном Ледовитом океане видов, произошедших от доплиоценовых глубоководных арктических предков. 12 родов (13\%), широко распространенных в Мировом океане, рассматриваются как наиболее вероятные примеры поднятия абиссальной фауны в Северном Ледовитом океане. Распространение двух родов ( $2 \%)$ характеризуется одновременно следующими чертами: (1) распространение ограничено северным полушарием, (2) широкий диапазон вертикального распространения, (3) абиссальные нахождения только в Северном Ледовитом океане и (4) чрезвычайно широкий спектр биотопов. Для этих родов предполагается погружение фауны из арктического шельфа до абиссальной зоны. Роды с такими же особенностями распространения могут составлять большую долю в некоторых макротаксонах, детально не рассматриваемых в настоящей работе. Например, доля родов, погрузившихся из арктического шельфа до абиссали, приблизительно равна 25\% в абиссальной арктической фауне амфипод.

КЛЮЧЕВЫЕСЛОВА: распространение, роды, Северный Ледовитый океан, абиссаль, погружение фауны, поднятие фауны.

\section{Introduction}

Different scenarios have been suggested for the origin of species prevailing in the Arctic abyssal fauna. Some authors suppose that the bulk of the Arctic abyssal fauna consists of immigrants from the Atlantic deep sea (Ekman, 1953; Filatova, 1962; Kussakin, 1979; Svavarsson et al., 1993; Smirnov, 1994; Sirenko et al., 2004; Bluhm et al., 2011; Krylova et al., 2013, and others). Others support the hypothesis of the origin of the Arctic abyssal fauna mainly from the Arctic shelf fauna. Gurjanova (1938, 1951, 1970, 1985a) was the most consistent in developing the latter hypothesis. According to Gurjanova (1951), colonization of the Arctic depths by shallow-water species resulted in speciation in the abyssal zone, primarily in the Greenland Basin and adjacent areas of the Central Arctic. Gurjanova suggested that this deepsea center of speciation occurred at the border between the Pliocene and the Pleistocene. She 
explained some similarity between deep-sea faunas of the Arctic Ocean and the North Atlantic by two reasons. First, few deep-sea North Atlantic taxa penetrated the Norwegian and Greenland Seas. As a rule these taxa did not disperse further to the north and north-east. Second, this similarity results from penetration of some deep-sea species of the Arctic origin into the North Atlantic. Koltun (1964) also mentioned the possibility of dispersal of deep-sea species from the Arctic to the northern Atlantic. Gurjanova (1985a) as well as Derjugin (1915), Andriashev (1985), Golikov and Scarlato (1989) and others used the term "pseudoabyssal" to emphasize the lack of connection between the Arctic abyssal fauna and the true abyssal fauna of the World Ocean. It was repeatedly suggested that part of the shallow-water Arctic fauna has survived during the glaciation owing to migration to the depths of the Arctic Ocean (Gurjanova, 1939, 1957; Koltun, 1964; Nesis, 1983, 2001; Golikov, Scarlato, 1989; Svavarsson et al., 1993; Clarke, 2003).

To justify the hypothesis of the shelf origin Gurjanova mainly used data on distribution and relationships of amphipod genera and species. Just (1980b) emphasized the difference between abyssal faunas of amphipods and isopods: the Arctic abyssal amphipods belong mainly to genera occurring on adjacent shelves, whereas the majority of the asellote isopods belong to widespread deep-sea genera. Dahl (1979) mentioned a similar difference between the amphipod and molluscan faunas. According to Dahl, the Recent amphipod deep-sea fauna of the Norwegian Sea has the closest connection at the species and generic levels with the Arctic and highboreal shelf fauna, whereas the deep-sea molluscan fauna seems to have no close affinity to the shelf fauna. A close relation is also suggested for shelf and abyssal fish fauna of the Arctic Ocean. As indicated by Haedrich and Krefft (1978), abyssal fish fauna of the Arctic Ocean consists of secondary deep-sea invaders from shallower depths. Andriashev (1985) believed that the true abyssal fish fauna of the World Ocean did not penetrate into the Arctic.
Most authors agree that colonization of the Arctic abyssal occurred relatively recently, in the Pleistocene. There is also a hypothesis about the pre-Pleistocene or even pre-Pliocene age of the Arctic abyssal fauna. Gorbunov (1946) suggested that some genera have no relatives on Arctic or boreal shelves and their abyssal species appeared before the first Quaternary glaciation. Menzies et al. (1973) believed that some endemic abyssal genera result from a step-wise evolution from shelf genera and species in the Pleistocene, whereas other genera that are evidently allied to abyssal genera in other oceans, submerged prior to the Pleistocene and their species and subspecies have evolved since then at abyssal depths. Bouchet and Warén (1979) presented a survey of the Arctic abyssal shellbearing molluscs: altogether 31 species of 28 genera have been recorded at depths below $2500 \mathrm{~m}$. The authors suggested that 10 species could be regarded as late Atlantic immigrants whereas 10 other species were more closely related to the abyssal Pacific fauna than to the Atlantic one. For the remaining 11 species the authors did not recognize any relatives. Bouchet and Warén (1979) gave the following explanation of the relationship to the North Pacific fauna: part of the deep sea Arctic fauna is a reminiscence of the old North Pacific fauna that lived in the Polar Basin before it was disconnected from the North Pacific by the Bering Strait. These species subsequently diverged only very slightly. Jirkov (2001) stated that the deepsea Arctic fauna is older than the Arctic shallow-water fauna. Sirenko et al. (2004) suggest that the high number of endemics in the Arctic bathyal and abyssal indicated a rather long period of evolution of the deep-sea Arctic fauna. At the same time the authors noted significant influence of the shelf fauna on the bathyal and even abyssal faunas of the Arctic Ocean.

Only three pathways of colonization of the Arctic abyssal can be suggested: via the deepsea North Atlantic (1), via the deep-sea North Pacific (2) and from the Arctic shelf-bathyal zone (3). However, the discussion about the biogeographical history of the Arctic abyssal fauna is considerably complicated by the fact 
that faunas of all these three regions are of a multiple origin (see section 7). Possible scenarios get even more complicated if one takes into account that one and the same species could penetrate the Arctic abyssal repeatedly and by different pathways.

The present work describes global distribution patterns of genera represented in the abyssal of the Arctic Ocean. Our main goal was to reveal the types of distribution of the groups of genera that have been most successful in the colonization of the Arctic abyssal. Based on the distribution patterns of the most successful groups of genera, we hypothesize the main donor regions for the abyssal Arctic fauna.

\section{Compilation of the genera list}

The Arctic Ocean is considered here within borders adopted in the "Atlas of the Arctic" (Leontjev, 1985; Treshnikov, 1985). The Norwegian, Greenland and Chukchi Seas are included in the Arctic Ocean. The 2000 m horizon was arbitrarily taken as the upper boundary of the abyssal zone. Species are designated as "Arctic" if they occur in the Arctic Ocean. Species are designated as abyssal if they are recorded in the abyssal. For purposes of the current paper, these terms are used in a wide context: Arctic species are not only the Arctic endemics, but also the Arctic-Pacific, ArcticAtlantic and cosmopolitan species; abyssal species are not only the abyssal endemics, but also bathyal-abyssal and sublittoral-abyssal species. Genera are designated as "abyssal" if they contain at least one abyssal species. (For different interpretations the notion 'Arctic species' see Jirkov, 2013; Mironov, 2013).

A complete list of genera recorded in the Arctic at depths exceeding $2000 \mathrm{~m}$ was compiled for eight classes (Scaphopoda, Bivalvia, Crinoidea, Echinoidea, Holothuroidea, Asteroidea, Ophiuroidea and Ascidiacea) and some orders from the classes Anthozoa, Maxillopoda and Malacostraca (Table 2). The abyssal Arctic fauna of these groups is the most studied. The list includes 92 genera (Table 1) and 133 species. Genera of Bivalvia known in the Arctic only by empty shells from deeper than $2000 \mathrm{~m}$ were not listed. Thus, Richling (2000) reported empty shells of the following genera deeper than 2000 m north of the Laptev Sea: Arctinula, Astarte, Cardiomya, Ciliatocardium, Cyrtodaria, Hiatella, Liocyma, Lyonsia, Macoma, Nuculana, Serripes, Similipecten and Yoldia. The genus Portlandia was included in the list of abyssal genera tentatively since data on its vertical distribution are inconsistent. Filatova (1951) mentioned live individuals of Portlandia arctica from 10-350 m depth, with empty shells occurring deeper than $2000 \mathrm{~m}$. In her opinion, the valves could be transported to the abyssal by currents and ice. Coan et al. (2000) believe that live $P$. arctica occur only to $500 \mathrm{~m}$. However, live specimens were reported by Bernard (1979) from $2560 \mathrm{~m}$ in the Beaufort Sea.

A list of selected genera occurring deeper than 2000 m was compiled for the Arctic Amphipoda. Genera in this list are those with a close relationship between the Arctic abyssal and shelf species. The list includes 16 genera out of 64 abyssal (Table 2). For each genus Tables 1 and 2 show the vertical distribution ranges of species recorded in the Arctic Ocean and species unknown in the Arctic Ocean. Depth ranges of the Arctic species are given for the World Ocean (not only for the Arctic basin).

Our list of genera is based on published sources. The main publications used are listed in Table 3. Three echinoderm genera were included in the list, based on unpublished data. One specimen of Myriotrochus (Holothuroidea) was found in the Canada Basin at depth of approximately $2500 \mathrm{~m}$ (RV Healy, 2005, leg. 02 , Sta. 15 , identified by A.N. Mironov). The genera Gracilechinus (Echinoidea) and Ceramaster (Asteroidea) were recorded in the Norwegian Basin at depth $2198 \mathrm{~m}$ (RV Sevastopol, cruise 8 , Sta. $1351,25.03 .58,69^{\circ} 39^{\prime} \mathrm{N}, 15^{\circ} 01^{\prime}$ W, identified by K.V. Minin and A.B. Dilman correspondingly).

Data on the total number of species in a genus were taken mainly from the World Register of Marine Species (WoRMS) (Appeltans et al., 2012). However, there were several exceptions. To six species indicated for the bivalve 
Table 1. Distribution of genera known from the Arctic Ocean at deeper than $2000 \mathrm{~m}$. NA - N Atlantic, SA - S Atlantic, NP - N Pacific, SP - S Pacific, IO — Indian Ocean, SO South Ocean, COS - cosmopolitan distribution. The boundary line between the North and South Atlantic and Pacific Oceans is the Equator. Таблица 1. Распространение родов, известных в Северном Ледовитом океане на глубинах более $2000 \mathrm{M}$. NA - Сев. Атлантика, SA - Южная Атлантика, NP - Сев. Пацифика, Южная Пацифика, IO Индийский океан, SO - Южный Океан, $\mathrm{COS}$ - космополитное распространение. Экватор принят за пограничную линию между северными и южными половинами Атлантического

и Тихого океанов.

\begin{tabular}{|c|c|c|c|c|}
\hline \multirow[b]{2}{*}{ Genera } & \multirow[b]{2}{*}{$\begin{array}{l}\text { Number of } \\
\text { species in the } \\
\text { genus (in the } \\
\text { Arctic Ocean*) }\end{array}$} & \multirow[b]{2}{*}{$\begin{array}{l}\text { Distribution of } \\
\text { species unknown } \\
\text { in the Arctic } \\
\text { Ocean }\end{array}$} & \multicolumn{2}{|c|}{ Depth range, $\mathrm{m}$} \\
\hline & & & $\begin{array}{c}\text { Species } \\
\text { known from } \\
\text { the Arctic } \\
\text { Ocean** }\end{array}$ & $\begin{array}{c}\text { Species } \\
\text { unknown in } \\
\text { the Arctic } \\
\text { Ocean }\end{array}$ \\
\hline \multicolumn{5}{|c|}{ Class ANTHOZOA } \\
\hline \multicolumn{5}{|c|}{ Subclass Hexacorallia } \\
\hline Amphianthus & $27(4 / 1)$ & $\begin{array}{c}\text { NA, SA, NP, SP, } \\
\text { IO }\end{array}$ & $130-3870$ & $0-5300$ \\
\hline Anthosactis & $7(2 / 1)$ & COS & $11-3337$ & $280-4100$ \\
\hline Antipodactis & $2(1 / 1)$ & $\mathrm{SO}$ & 2377 & $2852-3239$ \\
\hline Bathyphelia & $2(1 / 1)$ & $\mathrm{NP}, \mathrm{SO}$ & $400-5569$ & $3200-4575$ \\
\hline Cerianthus & $28(4 / 1)$ & $\begin{array}{c}\text { NA, SA, NP, SP, } \\
\text { IO }\end{array}$ & $0-2878$ & $0-5248$ \\
\hline Epizoanthus & $85(? 7 / 1)$ & $\begin{array}{l}\text { NA, SA, NP, SP, } \\
\text { IO }\end{array}$ & $73-2104$ & $5-4667$ \\
\hline Kadosactis & $5(2 / 1)$ & NA, SO & $475-2576$ & $70-4710$ \\
\hline Oceanactis & $3(1 / 1)$ & $\mathrm{NP}, \mathrm{SP}$ & $3012-3028$ & $558-1280$ \\
\hline Sagartiogeton & $12(1-2 / 1)$ & NA, NP, SP & $240-2410$ & $0-2145$ \\
\hline \multicolumn{5}{|c|}{ Class MAXILLOPODA } \\
\hline \multicolumn{5}{|c|}{ Order Scalpelliformes } \\
\hline Verum & $23(1 / 1)$ & $\begin{array}{c}\text { NA, SA, NP, SP, } \\
\text { IO }\end{array}$ & $348-3941$ & $204-4850$ \\
\hline \multicolumn{5}{|c|}{ Class MALACOSTRACA } \\
\hline \multicolumn{5}{|l|}{ Order Isopoda } \\
\hline Austroniscus & $10(1 / 1)$ & NA, SA, NP, SO & $2470-3642$ & $10-6850$ \\
\hline Balbidocolon & $2(1 / 1)$ & NA, SA, ?SP & 3350 & $1648-5389$ \\
\hline Caecognathia & $46(4 / 2)$ & $\mathrm{COS}$ & $0-3000$ & $0-2638$ \\
\hline Cryodesma & $2(2 / 2)$ & $\begin{array}{l}\text { Endemic to the } \\
\text { Arctic Ocean }\end{array}$ & $417-3672$ & - \\
\hline Desmosoma & $32(4 / 1)$ & $\mathrm{COS}$ & $17-2887$ & $20-6134$ \\
\hline Disconectes & $13(3 / 2)$ & $\mathrm{COS}$ & $54-3410$ & $15-7934$ \\
\hline Eugerda & $17(8 / 3)$ & $\mathrm{NA}, \mathrm{NP}$ & $4-3003$ & $30-4825$ \\
\hline Eugerdella & $19(2 / 1)$ & NA, SA, NP, SO & $16-3620$ & $24-6000$ \\
\hline Eurycope & $57(10 / 9)$ & COS & $46-3970$ & $213-9174$ \\
\hline Exiliniscus & $4(1 / 1)$ & NA, SA, NP & $80-3920$ & 1964-5023 \\
\hline Gracilimesus & $12(4 / 1)$ & NA, SA, NP, SP & $698-5494$ & $1491-4925$ \\
\hline Gurjanopsis & $2(1 / 1)$ & SO & 1279-3709 & $3405-4655$ \\
\hline Haplomesus & $5(1 / 1)$ & NA, SA, NP, SO & $365-4150$ & $2641-6135$ \\
\hline Haploniscus & $73(2 / 2)$ & COS & $698-5024$ & $385-8345$ \\
\hline Heteromesus & $18(1 / 1)$ & NA, SA, NP & $539-2104$ & $364-8330$ \\
\hline Ilyarachna & $41+? 12(7 / 5)$ & $\mathrm{COS}$ & $8-5223$ & $\begin{array}{l}50-7230 \\
(? 10687)\end{array}$ \\
\hline
\end{tabular}


Table 1 (continuing)

Таблица 1 (продолжение)

\begin{tabular}{|c|c|c|c|c|}
\hline Ischnomesus & $39(4 / 1)$ & $\mathrm{COS}$ & $94-2681$ & $274-8330$ \\
\hline Macrostylis & $80(5 / 2)$ & $\mathrm{COS}$ & $4-3510$ & $149-10730$ \\
\hline Mirabilicoxa & $19(1)$ & NA, NP, SP & $2194-3806$ & $530-6710$ \\
\hline Munna & $80(11 / 1)$ & $\mathrm{COS}$ & $0-3709$ & $0-3839$ \\
\hline Munneurycope & $12(1)$ & $\mathrm{COS}$ & $2370-2750$ & $400-8400$ \\
\hline Nannoniscus & $31(10 / 4)$ & $\mathrm{COS}$ & $40-5843$ & $4-6328$ \\
\hline Oecidiobranchus & $5(4 / 1)$ & NA, SP & $40-3920$ & 2055 \\
\hline Panetela & $3(1 / 1)$ & SA, NP & 3230 & $1427-5495$ \\
\hline Paramunnopsis & $4(1 / 1)$ & COS & $2675-3970$ & $0-3240$ \\
\hline Pseudomesus & $5(1 / 1)$ & NA, SA, NP, SP & $80-3709$ & $1119-5441$ \\
\hline Rapaniscus & $3(1 / 1)$ & NA, SA & $219-2754$ & $1254-5389$ \\
\hline Saduria & $4(4 / 3)$ & - & $0-3127$ & - \\
\hline Whoia & $4(1 / 1)$ & NA, SP & $1279-2024$ & $50-4892$ \\
\hline \multicolumn{5}{|l|}{ Order Mysida } \\
\hline Amblyops & $12+? 10(1 / 1)$ & $\mathrm{COS}$ & 49-2681 & $170-7230$ \\
\hline Amblyopsoides & $4(1 / 1)$ & $\mathrm{COS}$ & $1940-2681$ & $503-2928$ \\
\hline Birsteiniamysis & $2(1 / 1)$ & NP & $\begin{array}{c}750-7200 \\
(\mathrm{COS})\end{array}$ & (abyssal) \\
\hline Dactylamblyops & $15(1 / 1)$ & $\begin{array}{c}\text { NA, NP, SP, } \\
\text { IO, SO }\end{array}$ & $49-4320$ & $0 ?-350-4500$ \\
\hline Michthyops & $3(2 / 2)$ & NA & $27-3550$ & $200-2630$ \\
\hline Pseudomma & $44(4 / 1)$ & $\mathrm{COS}$ & $12-2340$ & $18-3425$ \\
\hline Pseudomysis & $2(1 / 1)$ & NP & $1421-3081$ & $500-1200$ \\
\hline \multicolumn{5}{|l|}{ Order Euphausiacea } \\
\hline Thysanoessa & $10(4 / 3)$ & $\mathrm{COS}$ & $0-3320$ & $0-3000$ \\
\hline \multicolumn{5}{|l|}{ Order Decapoda } \\
\hline Bythocaris & $17(10 / 5)$ & NA & $50-3800$ & $74-2120$ \\
\hline Hymenodora (pelagic) & $4(1 / 1)$ & $\cos$ & $\begin{array}{c}100-5440 \\
(\mathrm{COS})\end{array}$ & $0-5300$ \\
\hline Pasiphaea & $71(3 / 1)$ & $\cos$ & $\begin{array}{c}10-3219- \\
? 5551\end{array}$ & $0-2853$ \\
\hline \multicolumn{5}{|l|}{ Class SCAPHOPODA } \\
\hline Siphonodentalium & $18(2 / 2)$ & $\mathrm{COS}$ & $16-3254$ & $36-4734$ \\
\hline \multicolumn{5}{|l|}{ Class BIVALVIA } \\
\hline Axinulus & $8(3 / 1)$ & $\cos$ & $20-4632$ & $\begin{array}{c}42-7434 \\
(10015)\end{array}$ \\
\hline Bathyarca & $27(3 / 1)$ & $\mathrm{COS}$ & $6-4170$ & $0-5175$ \\
\hline Cuspidaria & $120(8 / 3)$ & $\mathrm{COS}$ & $0-4453$ & $0-7335$ \\
\hline Dacrydium & $29(2 / 1)$ & $\mathrm{COS}$ & $5-4060$ & $45-6150$ \\
\hline Ennucula & $47(3 / 1)$ & $\mathrm{COS}$ & $20-2250$ & $50-3910$ \\
\hline Hyalopecten & $10(1 / 1)$ & $\mathrm{COS}$ & $1060-3920$ & $400-7000$ \\
\hline Katadesmia & $7(1 / 1)$ & $\mathrm{COS}$ & $1036-3965$ & $523-7320$ \\
\hline Kelliola & $1(1 / 1)$ & - & $\begin{array}{c}892-2006- \\
4150 \\
\end{array}$ & - \\
\hline Mendicula & $7(4 / 3)$ & $\begin{array}{c}\text { NA, SA, NP, } \\
\text { SP, IO }\end{array}$ & $8-4825$ & $27-5223$ \\
\hline Myonera & $19(1 / 1)$ & $\cos$ & $2300-3709$ & $400-8035$ \\
\hline Nucula & $96(6 / 1)$ & $\mathrm{COS}$ & $5-2589$ & $5-4938$ \\
\hline Policordia & $25(2 / 1)$ & $\mathrm{COS}$ & $1223-3700$ & $73-9380$ \\
\hline
\end{tabular}


Table 1 (continuing) Таблица 1 (продолжение)

\begin{tabular}{|c|c|c|c|c|}
\hline ?Portlandia & $6(3 / ? 1)$ & NA, SO & $2-350-? 2560$ & $27-1334$ \\
\hline Tindaria & $28(1 / 1)$ & $\cos$ & $1125-3800$ & $\begin{array}{c}60-6210 \\
(7286)\end{array}$ \\
\hline Yoldiella & $98(13 / 5)$ & $\mathrm{COS}$ & $7-3800$ & $20-7333$ \\
\hline \multicolumn{5}{|c|}{ Class CRINOIDEA } \\
\hline Bathycrinus & $10(1 / 1)$ & COS & $460-3800$ & $693-9345$ \\
\hline Conocrinus & $? 6(1 / 1)$ & NA, NP, SP & $140-3135$ & $290-2070$ \\
\hline \multicolumn{5}{|c|}{ Class ECHINOIDEA } \\
\hline Gracilechinus & $8(3 / 1)$ & NA, SA, NP, SP & $20-4700$ & $120-2700$ \\
\hline Pourtalesia & $12(1 / 1)$ & $\mathrm{COS}$ & $220-3081$ & $227-7340$ \\
\hline \multicolumn{5}{|c|}{ Class HOLOTHUROIDEA } \\
\hline Acanthotrochus & $3(1 / 1)$ & $\mathrm{NP}, \mathrm{SO}$ & $1015-3900$ & $2800-4730$ \\
\hline Elpidia & $22(3 / 2)$ & $\mathrm{COS}$ & $70-5550$ & $650-9700$ \\
\hline Kolga & $3(1 / 1)$ & $\mathrm{NA}, \mathrm{SO}, \mathrm{NP}$ & $659-4106$ & $1484-6235$ \\
\hline Molpadia & $56(2 / 1)$ & $\mathrm{COS}$ & $40-2785$ & $4-5870$ \\
\hline Myriotrochus & $16(3 / 1)$ & $\mathrm{COS}$ & $2-2500$ & $2-9174$ \\
\hline Prototrochus & $19(2 / 1)$ & $\mathrm{COS}$ & $600-3900$ & $60-10687$ \\
\hline \multicolumn{5}{|c|}{ Class ASTEROIDEA } \\
\hline Bathybiaster & $2(1 / 1)$ & NA, SA & $160-3110$ & $80-880$ \\
\hline Ceramaster & $17(1 / 1)$ & $\begin{array}{c}\text { NA, SA, NP, SP, } \\
\text { IO }\end{array}$ & $40-2198$ & $0-2500$ \\
\hline Henricia & $79(9 / 1)$ & $\mathrm{COS}$ & $0-4204$ & $0-1635$ \\
\hline Hymenaster & $49(1 / 1)$ & $\mathrm{COS}$ & $15-3527$ & $405-9990$ \\
\hline Pontaster & $1(1 / 1)$ & - & $16-3440$ & - \\
\hline Poraniomorpha & $5(4 / 2)$ & NA & $9-3072$ & $2995-3740$ \\
\hline Tylaster & $1(1 / 1)$ & $\begin{array}{l}\text { Endemic to } \\
\text { the Arctic } \\
\text { Ocean }\end{array}$ & 79-2920 & - \\
\hline \multicolumn{5}{|c|}{ Class OPHIUROIDEA } \\
\hline Ophiacantha & $128(4 / 1)$ & $\mathrm{COS}$ & $7-4730$ & $0-6235$ \\
\hline Ophiocten & $21(2 / 1)$ & $\mathrm{COS}$ & $5-4500$ & $8-6070$ \\
\hline Ophiopleura & $2(1 / 1)$ & NA & $10-2500$ & $150-1875$ \\
\hline Ophioscolex & $8(1 / 1)$ & $\begin{array}{c}\text { NA, SA, NP, SP, } \\
\text { IO }\end{array}$ & $35-2727$ & $99-1246$ \\
\hline Ophiostriatus & $4(1 / 1)$ & $\begin{array}{l}\text { NA, SA, NP, IO, } \\
\text { SO }\end{array}$ & $270-4000$ & $40-6150$ \\
\hline \multicolumn{5}{|c|}{ Class ASCIDIACEA } \\
\hline Araneum & $2(1 / 1)$ & SP & $1386-5223$ & $570-610$ \\
\hline Asajirus & $6(1 / 1)$ & NA, SA, SP, IO & $\begin{array}{c}850-7420 \\
\text { (COS) }\end{array}$ & $600-4829$ \\
\hline Dendrodoa & $6(5 / 1)$ & NP & $0-2340$ & $0-12$ \\
\hline Styela & $82(6 / 1)$ & $\cos$ & $0-2195$ & $0-6330$ \\
\hline
\end{tabular}

* In brackets: numbers of species known from the Arctic Ocean and from the Arctic abyssal zone (>2000 m).

** Including occurrences outside the Arctic Ocean

* В скобках: число видов, встреченных в Северном Ледовитом океане и в Арктической абиссальной зоне $(>2000 \mathrm{M})$.

** включая нахождения за пределами Северного Ледовитого океана. 
Table 2. Distribution of the amphipod genera in the abyssal fauna with a presumed Arctic shelf origin.

Abbreviations as in Table 1.

Таблица 2. Распространение родов амфипод в абиссальной фауне, для которой предполагается происхождение от фауны Арктического шельфа. Сокращения как для таблицы 1.

\begin{tabular}{|l|c|c|c|c|}
\hline \multirow{2}{*}{ Genera } & Number of & Distribution of & \multicolumn{2}{c|}{ Depth range, m } \\
\cline { 4 - 5 } & $\begin{array}{c}\text { species in the } \\
\text { genus (in the } \\
\text { Arctic Ocean })\end{array}$ & $\begin{array}{c}\text { species unknown } \\
\text { in the Arctic } \\
\text { Ocean }\end{array}$ & $\begin{array}{c}\text { Species known } \\
\text { from the Arctic } \\
\text { Ocean }\end{array}$ & $\begin{array}{c}\text { Species } \\
\text { unknown in the } \\
\text { Arctic Ocean }\end{array}$ \\
\hline Aeginina & $2(2 / 1)$ & - & $5-2258$ & - \\
\hline Ambasia & $1(1 / 1)$ & - & $75-1096$ & - \\
\hline Apherusa & $20(10 / 1)$ & NA, NP & $0-2681$ & $0-126$ \\
\hline Arrhis & $4(2 / 1)$ & NA, NP & $10-3268$ & $100-105$ \\
\hline Boeckosimus & $13(13 / 1)$ & - & $5-3200$ & - \\
\hline Cleippides & $3(2 / 1)$ & NA & $28-2990$ & $1380-1900$ \\
\hline Deflexilodes & $15(8 / 1)$ & NA, NP & $5-2222$ & $0-200$ \\
\hline Halirages & $8(8 / 4)$ & - & $0-5375$ & - \\
\hline Haliragoides & $4(3 / 1)$ & SO & $30-2500$ & $16-18$ \\
\hline Ischyrocerus & $42(17 / 3)$ & COS & $0-2681$ & $0-2454$ \\
\hline Metacaprella & $4(1 / 1)$ & NP & $35-2365$ & $0-104$ \\
\hline Neohela & $5(3 / 1)$ & NP & $47-2806$ & $140-200$ \\
\hline Onisimus & $13(1 / 1)$ & Caspian Sea & $0-3300$ & $100-457$ \\
\hline Paroediceros & $5(4 / 1)$ & NA & $5-2681$ & $11-80$ \\
\hline Paronesimus & $1(1 / 1)$ & - & $24-2450$ & - \\
\hline Tmetonyx & $13(8 / 2)$ & NA, SO & $8-3800$ & $0-160$ \\
\hline
\end{tabular}

genus Axinulus in WoRMS, we added $A$. careyi Bernard 1979 and $A$. hadalis (Okutani, Fujikura, Kojima, 1999). Seven species listed in WoRMS for the bivalve genus Mendicula were supplemented by two abyssal species, which were earlier considered as representatives of the genus Thyasira: Thyasira (Mendicula) ockelmanni Keuning \& Schander, $2010(?=$ Thyasira sp.n. Bouchet \& Warén, 1979) and T. ottoschmidti Gorbunov, 1946. Therefore the genus Thyasira was not included in the list of Arctic abyssal genera. Following Bouchet and Warén (1979) and Knudsen (1985), we regard the bivalve Malletia abyssopolaris Clarke as a junior synonym of Tindaria derjugini. The number of species in the bivalve genus Portlandia was reduced from eight to six: P. glacialis was accepted as $P$. arctica and $P$. intermedia as Yoldiella intermedia. The composition of the holothurian genus Elpidia follows that of Gebruk and Rogacheva (2010) (see also Budaeva, Rogacheva, 2013). The composition of the genus Gracilechinus (Echinoidea) was modified after Minin et al. (2012; Minin, in preparation) who showed, based on molecular data, that the following 10 species should be assigned to this genus: G. acutus, G. affinis, G. alexandri, $G$. atlanticus, G. elegans, G. euryporus, G. gracilis, G. lucidus, G. multidentatus and G. stenoporus. WoRMS lists eight species each for the ascidian genera Asajirus Kott and Dendrodoa MacLeay. We did not accept all of them, after consultations with the expert Karen Sanamyan (6 species in Table 2). In particular, Asajirus arcticus was accepted as $A$. indicus with a cosmopolitan distribution.

Data on geographical and vertical distribution of 92 genera in the World Ocean were taken from several hundred publications. To characterize schematically the distribution of genera in the World Ocean, we divided it into seven large regions: the Arctic Ocean, North Atlantic (NA), South Atlantic (SA), North Pacific (NP), South Pacific (SP), the Southern Ocean (SO) and the Indian Ocean (IO). The boundary line between the North and South regions in the Atlantic and 
Table 3. Main publications used to compile the list of the Arctic abyssal genera (>2000 m). Таблица 3. Основные публикации, использованные для составления списка Арктических абиссальных родов (>2000 м).

\begin{tabular}{|l|l|}
\hline \multicolumn{1}{|c|}{ Class } & \multicolumn{1}{c|}{ Main publications } \\
\hline Anthozoa (Hexacorallia) & Daniellsen, 1890; Carlgren, 1913, 1942; Jensen, 1992; Fautin, 2006 \\
\hline $\begin{array}{l}\text { Maxilopoda } \\
\text { (Scalpelliformes) }\end{array}$ & Sars, 1886; Broch, 1953; Tarasov, Zevina, 1957 \\
\hline $\begin{array}{l}\text { Malacostraca (Decapoda, } \\
\text { Euphausiacea, Isopoda, } \\
\text { Mysida, Amphipoda) }\end{array}$ & $\begin{array}{l}\text { Sars, 1886; Hansen, 1916; Stephensen, 1923, 1925, 1931, 1944; } \\
\text { Gurjanova, 1946, 1951, 1964; Barnard et al., 1962; Bulycheva, 1964; } \\
\text { Lomakina, 1964; Dahl, 1979; Kussakin, 1979, 1982, 1988, 1999, 2003; } \\
\text { Just, 1980a, b; Petrashov, 1993, 2004; Svavarsson et al., 1993; } \\
\text { Malyutina, Kussakin, 1996a, b, c; Brandt, 1997, 2005; Sokolov, 2000; } \\
\text { Kamenskaya, 2001; Malyutina, Weisshappel, 2001; Vader et al., 2005; } \\
\text { Brix, Svavarsson, 2010 }\end{array}$ \\
\hline Scaphopoda & Bouchet, Warén, 1979; Ivanov, Zarubina, 2004 \\
\hline Bivalvia & Bernard, 1979; Bouchet, Warén, 1979; Knudsen, 1985; Richling, 2000 \\
\hline Crinoidea & Clark, 1970, Rogacheva et al., 2013 \\
\hline Echinoidea & Mortensen, 1903, 1907; Mironov, 1995; \\
\hline Holothurioidea & Madsen, Hansen, 1994; Rogacheva, 2007; Rogacheva et al., 2013 \\
\hline Asteroidea & Danielssen, Koren, 1884; Clark, 1989, 1993, 1996; Clark, Mah, 2001 \\
\hline Ophiuroidea & Mortensen, 1933; Djakonov, 1954; Stöhr, O'Hara, 2012 \\
\hline Ascidiacea & Hartmeyer, 1923; Millar, 1966; Monniot, Monniot, 1979 \\
\hline & $\begin{array}{l}\text { Gorbunov, 1946; Baranova, 1964; Koltun, 1964; Afanasjev, Filatova, } \\
\text { 1980; Smirnov, 1994; Kröncke, 1998; Deubel, 2000; Sirenko, 2001; } \\
\text { Sirenko et al., 2004; Smirnov, Smirnov, 2006; Budaeva et al., 2008; } \\
\text { Bergman et al., 2009; Soltwedel et al 2009; MacDonald et al., 2010; } \\
\text { Appeltans et al., 2012 }\end{array}$ \\
\hline
\end{tabular}

the Pacific Oceans is the equator. The zone of the Antarctic Convergence was taken as the northern boundary of the Southern Ocean. This zone is varying in latitude at different longitudes, extending across the Atlantic, Pacific and Indian Oceans between 48 and $61^{\circ} \mathrm{S}$. The Falkland Islands, Prince Edward Islands, Crozet Islands, Île Amsterdam, Île Saint-Paul, Tierra del Fuego and Macquarie Island lie north of the Antarctic Convergence. The Kerguelen Islands lie approximately on the Convergence. The South Shetland Islands, South Orkney Islands, South Georgia and the South Sandwich Islands, Bouvet Island, Heard Island and McDonald Islands all occur south of the Convergence. The macrotaxa we used include representatives of different ecological groups: benthic and pelagic forms, infaunal and epibenthic animals, errant and sedentary, filter-feeders, predators and detritophages, parasites and commensals. The diversity of macrotaxa and the number of abyssal genera used in the present work should be sufficient enough to reveal general distribution patterns characteristic of the Arctic abyssal macro- and megafauna. Meiobenthic taxa were excluded from our analysis.

\section{Species distribution patterns}

It was repeatedly mentioned in publications that the Arctic Ocean fauna is characterized by a high degree of endemism at the species level (Gurjanova, 1938, 1951, 1970; Gorbunov, 1946; Ekman, 1953; Menzies, 1963; Dahl, 1972, 1979; Menzies et al., 1973; Bouchet, Warén, 1979; Kussakin, 1979; Just, 1980b; Svavarsson et al., 1993, Vinogradova, 1997 and others). Our calculations confirm this conclusion. Species endemic to the Arctic Ocean comprise more than half of the Arctic abyssal faunal species (68 species, or 51\%) (Table 4). At the same time, the bulk of the Arctic abyssal fauna consists of eurybathic species with an upper distribution limit on the shelf or slope (Table 4). Among Arctic endemics occurring in the abyssal, only 25 species are endemics of the abyssal zone 
Table 4. Distribution patterns of Arctic abyssal species and genera. Таблица 4. Особенности распространения Арктических абиссальных видов и родов.

\begin{tabular}{|c|c|c|}
\hline \multirow[t]{2}{*}{ Distribution pattern } & \multicolumn{2}{|c|}{ Number of taxa } \\
\hline & species & genera \\
\hline The Arctic Ocean, $>2000 \mathrm{~m}$ & $133(100 \%)$ & $92(100 \%)$ \\
\hline \multicolumn{3}{|l|}{ I. Within the Arctic Ocean } \\
\hline Norwegian and Greenland Seas & $110(83 \%)$ & $87(94.5 \%)$ \\
\hline Norwegian and Greenland Seas only & $19(14 \%)$ & $11(12 \%)$ \\
\hline High-Arctic Basin & $113(85 \%)$ & $81(88 \%)$ \\
\hline High-Arctic Basin only & $22(16.5 \%)$ & $5(5.5 \%)$ \\
\hline Endemics to the Arctic Ocean & $68(51 \%)$ & $2(2 \%)$ \\
\hline \multicolumn{3}{|l|}{ II. Outside the Arctic Ocean } \\
\hline Common with N Atlantic & $62(47 \%)$ & $81(88 \%)$ \\
\hline N Atlantic and Arctic only & $42(31.5 \%)$ & $5(5.5 \%)$ \\
\hline Common with S Atlantic & $10(7.5 \%)$ & $63(68 \%)$ \\
\hline Common with N Pacific & $18(13.5 \%)$ & $73(79 \%)$ \\
\hline Common with S Ocean & $4(3 \%)$ & $53(58 \%)$ \\
\hline Common with north hemisphere & $63(47 \%)$ & $87(94.5 \%)$ \\
\hline Common with south hemisphere & $10(7.5 \%)$ & $79(86 \%)$ \\
\hline $\begin{array}{l}\text { World-wide distribution (4 and more regions, without the Arctic } \\
\text { Ocean) }\end{array}$ & $3(2 \%)$ & $60(65 \%)$ \\
\hline \multicolumn{3}{|l|}{ III. Most shallow depth of occurrence } \\
\hline Deeper than $2000 \mathrm{~m}$ & $27(20 \%)$ & $2(2 \%)$ \\
\hline Between 1001 and $2000 \mathrm{~m}$ & $16(12 \%)$ & $4(4 \%)$ \\
\hline Between 201 and $1000 \mathrm{~m}$ & $36(27 \%)$ & $22(24 \%)$ \\
\hline Between $0-200 \mathrm{~m}$ & $54(41 \%)$ & $64(70 \%)$ \\
\hline IV. Known in the hadal zone (deeper than $6000 \mathrm{~m}$ ) & $2(1.5 \%)$ & $34(37 \%)$ \\
\hline $\begin{array}{l}\text { V. Genera in which } \geq 50 \% \text { of species were recorded from } \\
\text { depths exceeding } 2000 \mathrm{~m}\end{array}$ & - & $55(60 \%)$ \\
\hline
\end{tabular}

whereas 43 species occur both shallower and deeper than $2000 \mathrm{~m}$. Hence, endemics of the abyssal zone in the Arctic Ocean comprise 19\% of the Arctic abyssal species fauna. Abyssal zone endemics are usually known only from a few records. For example, the following species are considered as endemics based on single record: the actinarians Antipodactis awii and Oceanactis bursifera, the isopods Balbidocolon polare, Cryodesma cryoabyssale, Eurycope septentrionalis, Eurycope vasinae and Panetela compacta and the ascidian Styela bathybia. Further studies will probably show that these species also occur shallower than $2000 \mathrm{~m}$, and that the share of the abyssal zone endemic species in the Arctic is much less than 19\%.

The abyssal fauna is rather homogeneous over the entire Arctic Ocean. The most marked difference is between the Norwegian/Green- land Seas and the high-Arctic Basin faunas: 92 species $(69 \%)$ occur both in the Norwegian/ Greenland Seas and the high-Arctic Basin, 19 species are distributed only in the Norwegian and Greenland Seas and 22 species occur only in the high-Arctic Basin. Pan-Arctic distribution is characteristic of many eurybathic endemics of the Arctic Ocean. These endemics are abundant and they define features of benthic communities over vast areas of the seafloor. For example, pan-Arctic endemic echinoderms Bathycrinus carpenteri, Pourtalesia jeffreysi, Ophiopleuraborealis, Elpidia belyaevi, E. heckeri and Kolga hyalina often dominate in the abyssal benthic communities.

Almost all Arctic abyssal species known outside the Arctic Ocean (62 out of 65) are common with the North Atlantic. Species common with other regions of the World Ocean are 
few (Table 4). This peculiarity suggests the distribution pathway of the Arctic deep-sea fauna via the North Atlantic.

Species with a bipolar distribution are not known. Species with a cosmopolitan distribution are very few: the benthopelagic shrimp Hymenodora glacialis (100-5440 m), the benthopelagic mysid Birsteiniamysis inermis (750-7200 m) and the benthic ascidian Asajirus indicus (850$7420 \mathrm{~m}$ ). In some genera there are pairs of species with one being endemic of the Arctic Ocean and the other being widely distributed in the World Ocean except for the Arctic. For example, the Arctic endemic Paramunnopsis justi (2675-3970 $\mathrm{m})$ and the widely distributed $P$. oceanica (0$2300 \mathrm{~m}$ ), Munneurycope glacialis (2370-2750 $\mathrm{m})$ and $M$. murrayi (400-7800 m).

Rare examples of deep-sea cosmopolites in other benthic taxa are the brachiopod Pelagodiscus atlanticus (366-5530 m, empty shells down to $7600 \mathrm{~m}$ ) (Zezina, 1980), the sipunculids Golfingia vulgaris $(0-5853 \mathrm{~m})$, Nephasoma minutum (0-6170 $\mathrm{m}$ ) and Phascolion strombus (1-4030 m) (Murina, 1961; Murina, Sørensen, 2004), the amphipods Eurythenes gryllus (550-7800 m) (Brandt et al., 2012) and Scina borealis (50-3000 m) (Bulicheva, 1964; Vinogradov et al., 1996) and the polychaetes Amphicteis gunneri (12-7686 m) and Notomastus latericeus (0-6230 m). Cosmopolitan species in general are rather rare in the abyssal mega- and macrofauna of the Arctic Ocean. They are more characteristic for meiofauna and plankton. The share of species with a world-wide distribution probably reaches a maximum in the biota of planktonic protozoans. For instance, there are 34 species with the Arctic-boreal-tropical distribution, 9 bipolar species and 12 cosmopolitan among the Arctic planktonic dinoflagellates (Okolodkov, 1999). True Arctic species among planktonic dinoflagellates (Okolodkov, 1999) and planktonic diatoms (Beklemishev, Semina, 1986) are not known.

\section{Distribution patterns of genera}

Endemics of the Arctic Ocean, among the abyssal genera, comprise only $2 \%$ : the isopod
Cryodesma with two species and the asteroid Tylaster with a single species (Table 1). Both genera are eurybathic and widely distributed within the Arctic Ocean. The abyssal fauna of the Arctic Ocean almost entirely consists of eurybathic (bathyal-abyssal, sublittoral-abyssal, bathyal-hadal and sublittoral-hadal) genera (Tables 1 and 4). There are no genera endemic to the Arctic abyssal.

Most genera are represented in the Arctic Ocean by only a few species. In the majority of genera ( 73 out of 92 , or $79 \%$ ) there is only one Arctic abyssal species. In 44 of these, the abyssal species is the only Arctic species in the genus. The highest number of Arctic species (13, with 5 being abyssal) is found in the bivalve genus Yoldiella. The highest number of Arctic abyssal species (9) is recorded in the genus Eurycope (Table 1).

The generic composition of the abyssal fauna changes markedly at the transition from the Norwegian and Greenland Seas to the Arctic Basin: 11 genera (12\%) are known only in the Norwegian and Greenland Seas, and five occur only in the Arctic Basin (Table 4).

Most Arctic genera (55 or $60 \%$ ) can be characterized as "true" deep-sea genera, with half or more of species (per genus) recorded from depths exceeding $2000 \mathrm{~m}$. Every third genus $(37 \%)$ is known from the hadal zone $(>6000 \mathrm{~m}$ ) outside the Arctic Ocean (Tables 1 and 4). The share of genera known from the hadal is probably higher in the Arctic abyssal than in the abyssal of other oceans. For example, the share of hadal genera in echinoids is $50 \%$ in the Arctic abyssal and only $14 \%$ (6 out of 44 genera) in the abyssal zone outside the Arctic Ocean; the respective shares of hadal genera are $50 \%$ and $15 \%$ ( 3 out of 20 genera) in the stalked crinoids, and $60 \%$ and $23 \%$ (25 of 107 genera) in the bivalve abyssal fauna.

All abyssal Arctic genera can be divided into two groups, with regard to the extent of their distribution ranges in the World Ocean: genera with a world-wide distribution and genera with a limited distribution. Among the first, each genus is known outside the Arctic in four or more regions, whereas in the second group each 


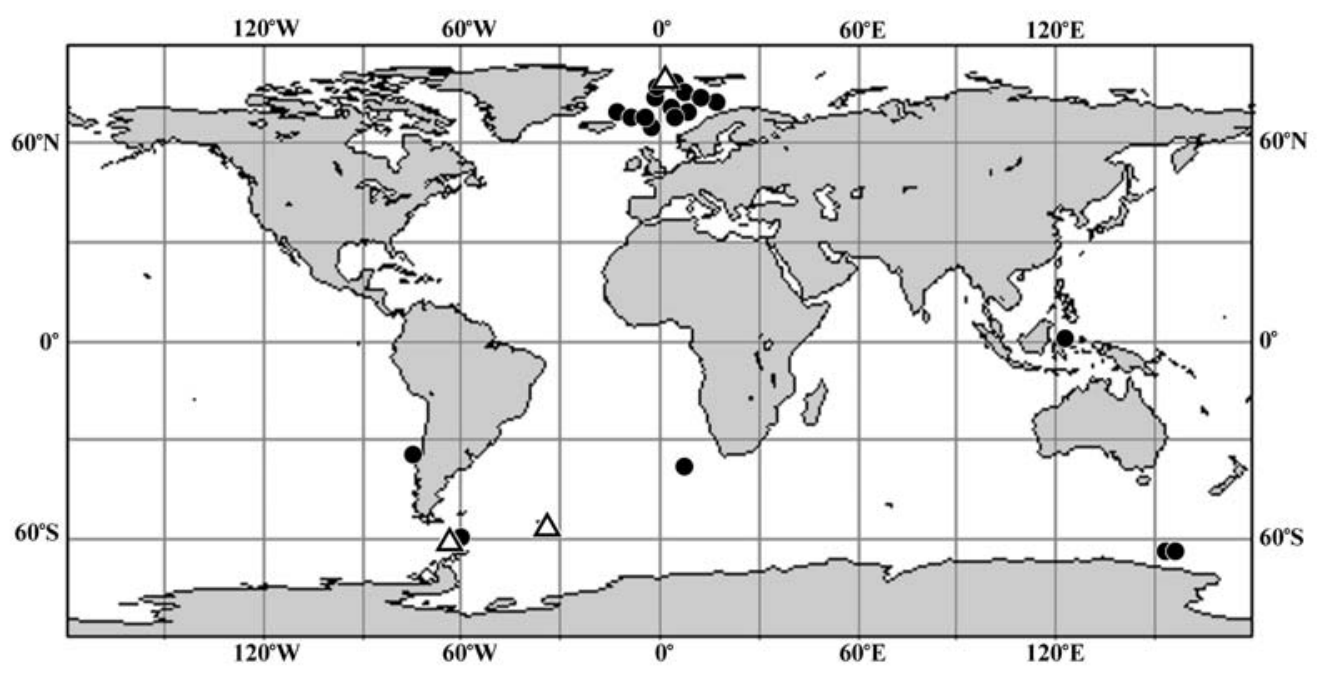

Fig. 1. Examples of genera with a disjunct distribution in the Atlantic Ocean. Distribution of sea anemones Antipodactis, at 2377-3239 m (triangles) and holothurians Acanthotrochus, at 1015-4730 m (circles). After Rodríguez et al. (2009), Belyaev and Mironov (1981), Madsen and Hansen (1994).

Рис. 1. Примеры родов с разрывом в распространении в Атлантическом океане. Распространение актиний Antipodactis, глубины 2377-3239 м (треугольники) и голотурий Acanthotrochus (кружочки), глубины 1015-4730 м. По Rodríguez et al. (2009), Беляеву и Миронову (1981), Madsen and Hansen (1994).

genus occurs in three or less regions. Genera with world-wide distribution dominate in the Arctic abyssal fauna: 60 or $65 \%$ (Table 4). These genera are usually species-rich, with four species and more. An exception is the isopod genus Birsteiniamysis with only two species, the cosmopolitan B. inermis and the North Pacific B. caeca.

Genera with a limited distribution (32 or $35 \%$ ) generally contain fewer species: 21 genera with 1-4 species and 11 genera with more than 4 species. Among genera with limited distribution, the following are bipolar: Antipodactis (Fig. 1), Bathyphellia, Kadosactis, Gurjanopsis and Kolga. These genera occur in high northern and southern latitudes but are absent in low latitudes. The ranges of genera Oceanactis, Whoia, Portlandia and Bathybiaster are with wide disjunction in the equatorial zone (antitropical distribution). But they are either not known from the Southern Ocean or occur off Kerguelen (Portlandia), at the northern limit of the Southern Ocean. Thirteen genera are unknown from the Southern Hemisphere. At least half of species in each of these genera occur in the Arctic (Table 1). Most genera in this group (9 out of 13) have their maximum depth of occurrence in the Arctic Ocean. Genera with a limited distribution generally show a higher linkage to the North Atlantic fauna than to the North Pacific: seven genera are common with the North Atlantic, two with the North Pacific, two both with the North Atlantic and the North Pacific and two are endemic to the Arctic Ocean. This pattern also supports the hypothesis about colonization of the Arctic abyssal mainly through the North Atlantic. Additional data on Arctic genera not found in the Southern Hemisphere are given below, in sections 5 and 8 .

\section{Deep-sea North Atlantic as a transit region}

In theory thare are three pathways of colonization of the Arctic abyssal (see Introduction): from the deep-sea North Atlantic, the deep-sea North Pacific and from the Arctic shelf-bathyal. The main pathway is from the deep North Atlan- 
tic. Examples of colonization from the Arctic shelf are much fewer (see sections 7 and 8). Reliable examples of dispersal from the deepsea North Pacific directly to the deep-sea Arctic are unknown.

The deep-sea fauna of the North Atlantic can be divided by origin into the following groups of species: (1) having dispersed without speciation from southern deep-sea regions, such as the Indo-West Pacific, Southern Ocean and South Atlantic, (2) species of the North Atlantic origin deriving from southern deep-sea species, (3) having dispersed without speciation from shallow waters of the North Atlantic; (4) species of the North Atlantic deep-sea origin deriving from shallow-water North Atlantic species, (5) species of deep-sea origin in the North Atlantic (speciation in the North Atlantic deep-sea), (6) having dispersed from the deep-sea Arctic Ocean (without speciation) and (7) having radiated from the Arctic deep-sea species. Each of these groups can be a potential donor of the Arctic abyssal fauna.

Two deep-sea families, the holothurians Elpidiidae and the echinoids Pourtalesiidae, give good examples of the transit role of the North Atlantic on the way to the Arctic. The biogeographical history of these families is connected with the deep-sea Antarctic centre of marine fauna redistribution (Belyaev, 1975; Mironov, 1980, 1982, 2006a, 2008; Gebruk, 1994; Rogacheva, 2007; see also below, section 7). The elpidiids Elpidia and Kolga are represented in the North Atlantic by E. gracilis and K. nana with a North Atlantic - Antarctic distribution. Both species belong to the first group by origin. The Arctic species of Elpidia and Kolga are endemic to the Arctic and they are more closely related to the North Atlantic-Antarctic species than to the North Pacific species (Rogacheva, 2007, 2011; Budaeva, Rogacheva, 2013). The North Atlantic species of Pourtalesia do not occur in the Antarctic or Indo-West Pacific, they belong to the second group of species. The Arctic endemic $P$. jeffreysi is closely related to Pourtalesia sp. from the Rockall Trough.

The example of species from the third group is the echinoid Gracilechinus acutus. It is known from the west Barents Sea southward to the Angola coast and the Walvis Ridge at depths 20$2635 \mathrm{~m}$. This species (and the genus as a whole) is known from the Arctic abyssal (2198 m) only from single occurrence in the Norwegian Sea. Both the genus and the species are of the North Atlantic shelf origin (Tyler, Young, 1998; Mironov, 2006; Minin, 2012; Rogacheva et al., 2013). Recent molecular studies support this scenario (Minin et al., 2012; Minin, pers. com.).

The sublittoral-abyssal genera Michthyops, Bythocaris, Poraniomorpha and Ophiopleura are known, besides in the Arctic, only in the North Atlantic. Thus, their North Atlantic species belong to one of the groups of the North Atlantic or Arctic origin (groups 3-7).

Some abyssal Arctic species lack close relatives in the North Atlantic. The corresponding genera dispersed via the North Atlantic without settling in this region. For example, the Arctic stalked crinoid Bathycrinus carpenteri is not closely related to the North Atlantic $B$. gracilis, but is similar to the $B$. australis. The latter occurs in the Antarctic, the Argentina Basin, the Angola Basin and north of the Kermadec Trench (Eléaume et al., 2012). The Arctic isopod Balbidocolon polare also differs considerably from the North Atlantic species B. atlanticum (Malyutina, Kussakin, 1996b).

The actinarian Antipodactis and the holothurian Acanthotrochus occur in the Arctic Ocean only in the Greenland/Norwegian Basin (Fig. 1). Both genera are not known from the North Atlantic. Outside the Arctic Ocean, Antipodactis was recorded only in the Southern Ocean (Rodríguez et al., 2009) and Acanthotrochus was found in the Southern Ocean and the Celebes Sea (Belyaev, Mironov, 1981). These two genera either did not settle in the North Atlantic dispersing through this region or became extinct there.

Genera with species from groups 1 and 2 (related to southern species) are much more numerous in the Arctic abyssal fauna than others. This suggests that the southern deep-sea regions (the Indo-West Pacific and the Southern Ocean) were the main donors of the Arctic abyssal fauna. 


\section{Probable pre-Pliocene deep-sea fauna of the Arctic Ocean}

Data on macrofauna of the Arctic Ocean in the Paleogene and the Miocene are almost completely lacking. Among the Recent bivalve molluscs only Cyrtodaria was found in the Arctic pre-Pliocene deposits (Nesis, 1965; Strauch, 1972; Kafanov, 1979). This genus includes two Recent species, C. kurriana and C. siliqua, and 5 extinct ones. Today, C. kurriana is distributed throughout the Arctic (circumpolar) and in the North Pacific, whereas C. siliqua is known only from the North Atlantic. Live Cyrtodaria were found at 1-165 $\mathrm{m}$ depth, empty shells were recorded in the Arctic down to 3076-3081 m depth (Richling, 2000). There are also reports of C. kurriana from the Arctic bathyal and abyssal without indication of condition (live or dead) of the molluscs (Gorbunov, 1946; Rosenberg, 2009). Gorbunov (1946) reported C. kurriana from depths of 1475-1510 $\mathrm{m}$ and 1630 $1900 \mathrm{~m}$ (Sadko Sts. 98 and 99). According to Rosenberg (2009) C. kurriana occurs at depths from 1 to $2362 \mathrm{~m}$.

The distribution of Cyrtodaria has changed over geological time. Paleocene records are in the Arctic Ocean (Svalbard) and England, Middle-Upper Oligocene - in Europe, the northern Ustyurt (between the Caspian and Aral Seas), the Turgai Depression (the northern Kazakhstan), Miocene - in Europe and Northern Alaska; Pliocene-Pleistocene - in Europe, Iceland, Greenland, Canadian and Russian Arctic. Both Recent species of Cyrtodaria are known as fossils. The oldest late glacial ages available for C. kurriana are from the Western Canadian Arctic Archipelago $\left(11.5{ }^{14} \mathrm{C} \mathrm{ka} \mathrm{BP}\right)$ and the Laptev Sea $\left(<10.3{ }^{14} \mathrm{C}\right.$ ka BP) (England, Fueze, 2008). If the abyssal occurrence of live $C$. kurriana is confirmed, Cyrtodaria will be the only abyssal genus known from the Arctic prePliocene.

There are two extant genera, Laubiericoncha and Saracrinus, recorded in the Arctic abyssal as fossils but not known in the Recent Arctic fauna. The fossil valves of Laubiericon- cha sp. were collected at the Gakkel Ridge (77462 N 126072 E, 1992-2054 m) (Sirenko et al., 1995; Krylova, Sahling, 2010; Krylova et al., 2011). The age was estimated about $15.7 \mathrm{kyr}$ (late Pleistocene) (Sirenko et al., 1995). The genus Laubiericoncha includes four species known from low and temperate latitudes of the Pacific and Atlantic Oceans at depths from 1323 to $3159 \mathrm{~m}$ (Krylova, Sahling, 2010) all restricted to sulphide-rich reducing environments. A fragment of stalk of the crinoid Saracrinus sp. was found in the Canada Basin (the drifting station North Pole-22, St. 29, 26.07.1977, $80^{\circ} \mathrm{N}, 128^{\circ} \mathrm{E}, 2630-2910 \mathrm{~m}$ ) (Afanasjev, Filatova, 1980; Klikushin, 1992). The age of the fragment was not identified. Good preservation of relief on the columnal articulate surface indicates a probable young (?Pleistocene) age. The genus Saracrinus belongs to the family Isselicrinidae Klikushkin, 1977. The family is known from the Upper Cretaceous deposits (Hess, 2011). Presently Isselicrinidae occur mostly at low latitudes. The species Endoxocrinus (Diplocrinus) wyvillethomsoni is the most deep-water and most northern in the family, it occurs from Morocco to the Bay of Biscay at depths from 1246 to $2070 \mathrm{~m}$. It can be suggested that the stalked crinoids of the family Isselicrinidae were present in pre-Pliocene Arctic deep-sea fauna but became extinct.

\section{Arctic emergence}

In the present study the "emergence" and "submergence" of fauna are considered from the viewpoint of historical biogeography. We use the terms emergence and submergence to designate trends in faunal dispersal during the Pliocene-Pleistocene colonization of the Arctic Ocean. "Emergence" corresponds to the rise of fauna from deeper waters to shallower depths and the opposite trend is "submergence" (descent).

Shorygin (1928) showed that several species of echinoderms occur in the Arctic at shallower depths than in the North Atlantic. For example, the upper boundary of occurrence of 


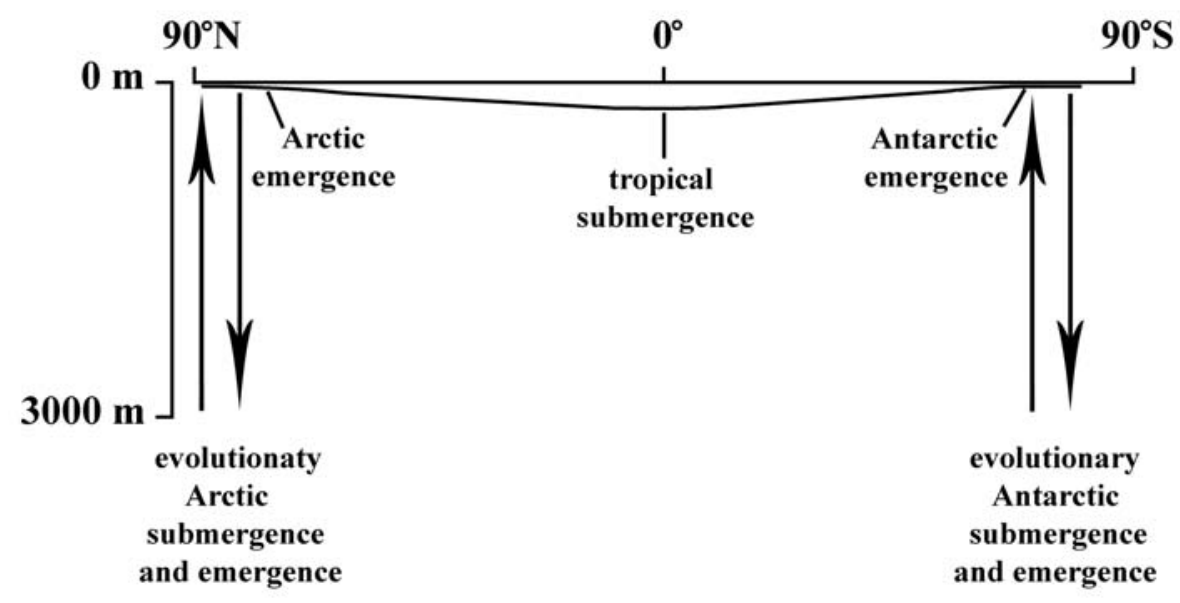

Fig. 2. Sketch of polar emergence/tropical submergence in the distribution of a taxon and the evolutionary polar emergence/polar submergence in biogeographical history of a taxon. The curve shows the upper limits of the bathymetrical ranges of a taxon. Vertical rows show two opposite vectors of vertical dispersal of polar faunas in the Pliocene and the Pleistocene.

Рис. 2. Схематическое изображение полярной эмергенции/тропической субмергенции в распространении таксона и эволюционой порлярной эмергенции/полярной субмергенции в биогеографической истории таксона. Кривая линия показывает верхний предел вертикального распространения таксона. Вертикальные стрелки показывают два противоположных направления распространения по вертикали полярной фауны в плиоцене и плейстоцене.

the abyssal Ophiacantha bidentata near the southern range border is at the depth $800 \mathrm{~m}$, in the middle of boreal zone at $200-300 \mathrm{~m}$, in the northern boreal at $100 \mathrm{~m}$, in the low Arctic at $10-25 \mathrm{~m}$ and in the high Arctic at $5 \mathrm{~m}$ (Shorygin (1928). This phenomenon was called the "boreal submergence" by Ekman(1953). Ekman considered the boreal submergence as a particular manifestation of a broader phenomenon - the equatorial submergence: when a species or a genus at high latitudes occurs in shallow waters and appears at greater depths at low latitudes. The term "submergence" has been introduced by Häcker (1904) who pointed to this tendency in pelagic radiolarians. The equatorial or tropical submergence usually is explained by the influence of temperature and illumination on vertical distribution of animals (Sverdrup et al., 1942; Ekman, 1953; Schmitt, Kott, 1969; Hessler, 1970b). Cold-water animals need colder, deeper waters in regions with warm surface water (Ekman, 1953: 249).
Based exclusively on chorological (bathymetric) characteristics, Ekman's phenomenon of boreal submergence can be designated as the "Arctic emergence". In other words, one and the same phenomenon can be described in different terms depending on the point of view. Bathymetric patterns of a taxon in the Arctic Ocean and the North Atlantic can be compared in terms of the Arctic emergence (Filatova, Zenkevitch, 1957; Zenkevitch, 1963; Shchedrina, 1964; Svavarsson et al., 1993; Kosobokova, 2010). Thus, according to Zenkevitch (1963: 63) many members of the abyssal fauna of the Arctic Basin have risen into the comparatively shallow zones along its fringes in seas with Arctic conditions. Zenkevitch explained the Arctic emergence of some taxa by the following four reasons: (1) lower temperature of surface water in the high Arctic, (2) small annual temperature fluctuations, (3) comparatively low transparency of water and (4) obscuration caused by the ice cover lasting almost the year round. 
Table 5. Species of asselote isopods with an upper depth boundary in the Arctic Ocean shallower than in the North Atlantic. All species belong to the Arctic abyssal genera. The difference between the Arctic and Atlantic minimum depths is more than $100 \mathrm{~m}$. After Svavarsson et al. (1993, Table 1), except for depth values marked by asterisk.

Таблица 5. Виды асселотных изопод, у которых верхний предел распространения в Северном Ледовитом океане расположен на меньших глубинах, чем в Северной Атлантике. Все виды принадлежат к арктическим абиссальным родам. Разница между минимальными глубинами обитания в Северном Ледовитом океане и Атлантике более 100 м. По Svavarsson et al. (1993,

Table 1), за исключений глубин, помеченных звездочкой.

\begin{tabular}{|l|c|c|}
\hline \multirow{2}{*}{ Species } & \multicolumn{2}{|c|}{ Depth range, m } \\
\cline { 2 - 3 } & Within the Arctic Ocean & Within the North Atlantic \\
\hline Desmosoma lineare & $17-531$ & $172-1564^{*}$ \\
\hline Disconectes furcatus & $150-350$ & $390^{*}-2258$ \\
\hline Disconectes phalangium & $54-681$ & $478-1597$ \\
\hline Eugerdella coarctata & $24-350$ & 2702 \\
\hline Eurycope brevirostris & $160-1501$ & $1505-3423^{*}$ \\
\hline Eurycope inermis & $200-2380$ & $682-1518$ \\
\hline Eurycope producta & $72-2681^{*}$ & $309-2087$ \\
\hline Gracilimesus angustus & $698-1373$ & 2137 \\
\hline Haplomesus quadrispinosus & $365^{*}-3672$ & $2258-4150$ \\
\hline Haploniscus ingolfi & $854-2465$ & $2892^{*}-4100$ \\
\hline Ilyarachna hirticeps & $20-3270$ & $2239-2496$ \\
\hline Ilyarachna longicornis & $8-3824 *$ & $364-5223$ \\
\hline Ischnomesus bispinosus & $10-537$ & $344^{*}-1100$ \\
\hline Macrostylis spinifera & $4-681$ & $542 *-1760$ \\
\hline Macrostylis subinermis & $830-2105$ & $2800^{*}-3474$ \\
\hline Munna acanthifera & $60-3709$ & $584-2258$ \\
\hline Munna boecki & $37-188$ & $320-350$ \\
\hline Munna hanseni & $90-1020$ & $913-1505$ \\
\hline Oecidiobranchus plebejum & $80-1666$ & $1330-1610$ \\
\hline Rapaniscus crassipes & $219-457$ & $1300-2754$ \\
\hline Whoia angusta & $50-680$ & $824-2500$ \\
\hline
\end{tabular}

When bathymetric patterns are considered from the viewpoint of historical biogeography, the terms submergence and emergence designate two different events: dispersal of fauna from the shelf to the deep sea and dispersal in the opposite direction (Fig. 2). In evolution of faunas, emergence and submergence should be discussed in terms of historical factors but not peculiarities of the modern environment (see below).

The Arctic species (including those with the Arctic-boreal distribution) occur shallower than non-Arctic species in 39 (42\%) abyssal genera (Table 1). Among those genera, in 24 the difference between the minimum depth of occurrence in the Arctic and non-Arctic species is $>100 \mathrm{~m}$. There is also difference between the minimum depth of occurrence at the intraspecies level (Table 5).

The probability of evolutionary Arctic emergence is highest for 12 abyssal genera. They include Ilyarachna and Pourtalesia, the classic examples of evolutionary emergence of the deepsea fauna (Hessler, Thistle, 1975; Mironov, 1975, 2008; Hessler et al., 1979). Ilyarachna is the most speciose (41 species) and the most eurybathic (8-7230-?10687 m) genus in the subfamily Ilyarachninae, family Munnopsidae. Recent molecular studies supported the hypothesis of the deep-sea origin of Ilyarachna. According to $18 \mathrm{~S}$ and $28 \mathrm{~S}$ Bayesian analyses, Ilyarachna forms a monophyletic group together with Echinozone and Notopais, whereas Syneurycope is suggested as their sister group 
(Osborn, 2009; Raupach et al., 2009). The deepsea distribution of the basal genus Syneurycope (1280-5122 m) suggests the deep-sea origin of Ilyarachna. This genus ascended to depths shallower $100 \mathrm{~m}$ in three areas: the Arctic Ocean ( $I$. longicornis, minimum depth $8 \mathrm{~m}$ ), the Southern Ocean (I. nordenstami, $50 \mathrm{~m}$ ) and southern California (I. acarina, $80 \mathrm{~m}$ ). Most species of this genus (28) occur at the depth exceeding $2000 \mathrm{~m}$.

Pourtalesia is the most species-rich (12 species) and the most eurybathic (220-7340 m) genus in the family Pourtalesiidae. Among nine genera of the family, only Pourtalesia was recorded at depths shallower than $1000 \mathrm{~m}$. Shallow-water records were in the Arctic Ocean $(P$. jeffreysi, minimum depth $220 \mathrm{~m})$, the NorthWest Pacific (P. laguncula, $227 \mathrm{~m}$ ), the Southern Ocean (P. aurorae, $432 \mathrm{~m})$ and the Caribbean $(P$. miranda sensu stricto, $450 \mathrm{~m})$. Most species of the genus occur at depths exceeding $2000 \mathrm{~m}$ (Fig. 3). In the northern Atlantic the genus was not recorded shallower than $1000 \mathrm{~m}$. Morpho-functional (Mironov, 1975, 1982, 2008) and molecular studies (Petrov et al., 2012) indicate the deep-sea origin of Pourtalesia. Mironov (op.cit.) grouped genera of echinoids according to increasing morphological specialization to life within the deep-sea sediment. The least specialized genera show the most limited vertical and geographical distribution: they occur only in the abyssal of the Southern Ocean and the East and North Pacific. The most specialized genera are eurybathic and cosmopolitan, occurring from the upper bathyal to hadal worldwide, from the Southern Ocean to the Arctic. Only the most specialized genera (Pourtalesia, Echinosigra and Solenocystis) were found in the northern Atlantic and only the species Pourtalesia jeffreysi was reported from the Arctic Ocean. The following trend generally is common in the family Pourtalesiidae: the more advanced is a genus the broader is its vertical and geographical distribution (Mironov, 1975, 2008). Occurrence of Pourtalesia in the Arctic Ocean is an illustration of this trend.

The phylogeny of pourtalesiids, including the Arctic endemic Pourtalesia jeffreysi, based on mitochondrial genes $16 \mathrm{~S}$ rRNA and cytochrome oxidase (COI) 14 (Petrov et al., 2012) supports the evolutionary line from Cystocrepis to Pourtalesia (Mironov, 2008) and emergence of the abyssal fauna of pourtalesiids (Mironov, 1975). Cystocrepis, basal in this line, is not known shallower than $2000 \mathrm{~m}$, whereas the advanced Pourtalesia ascends in the Arctic to $220 \mathrm{~m}$ (Fig. 3).

Global distribution patterns, similar to those in Ilyarachna and Pourtalesia, are common for a number of other genera: Anthosactis, Eurycope, Gracilimesus, Haplomesus, Ischnomesus, Macrostylis, Pseudomesus, Amblyops, Bathycrinus, Elpidia, Kolga and Hymenaster. These genera are widely distributed in the World Ocean and include many species occuring outside the Arctic Ocean (except for Kolga). They belong to mainly deep-sea families with a typical deep-sea distribution. The shallowest record in each of these genera is in the Arctic, the difference between the minimum depth of occurrence in the Arctic and elsewhere is more than $100 \mathrm{~m}$. It can be suggested that genera with such a distribution pattern emerged in the Arctic Ocean.

The cosmopolitan genera Macrostylis (Isopoda) and Elpidia (Holothuroidea) demonstrate interesting examples of bipolar emergence (both in the Arctic and Antarctic). Macrostylis is the only genus in the family Macrostylidae. It includes 82 species and has the widest depth range among the isopod families (Riehl, Brandt, 2010; Riehl et al., 2012). The deepest record at 10730 $\mathrm{m}$ has been reported from the Mariana Trench (Mezhov, 1993). Most species (71, or 87\%) were not recorded shallower $2000 \mathrm{~m}$. Only the following eight species occur at depths $<1000$ $\mathrm{m}$ : M. abyssicola (Davis Strait and Kara Sea, 698-3921 m), M. gerdesi (Southern Ocean, Maud Rise, 238 m), M. longipes (Iceland, western Norway and the Canada Basin, 325-1412 $\mathrm{m}$ ), M. longiremis (Skagerrak and west of Iceland, 149-228 m), M. polaris (outer Chukchi shelf, 325-340 m), M. setulosa (Southern Ocean, Scotia Sea, 757-2705 m), M. spinifera (North Atlantic, Norwegian Sea, 4-1761 m) and $M$. subinermis (Davis Strait, Norwegian and Green- 


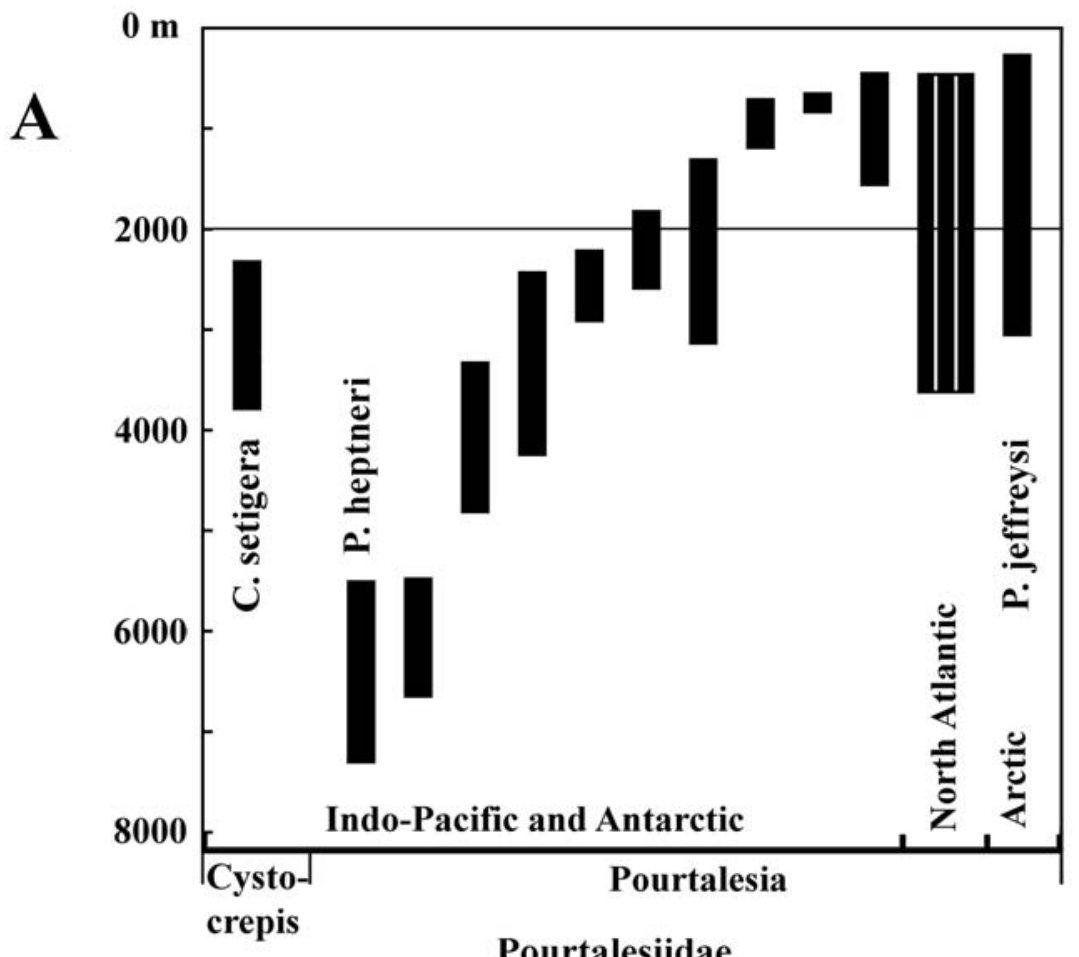

B

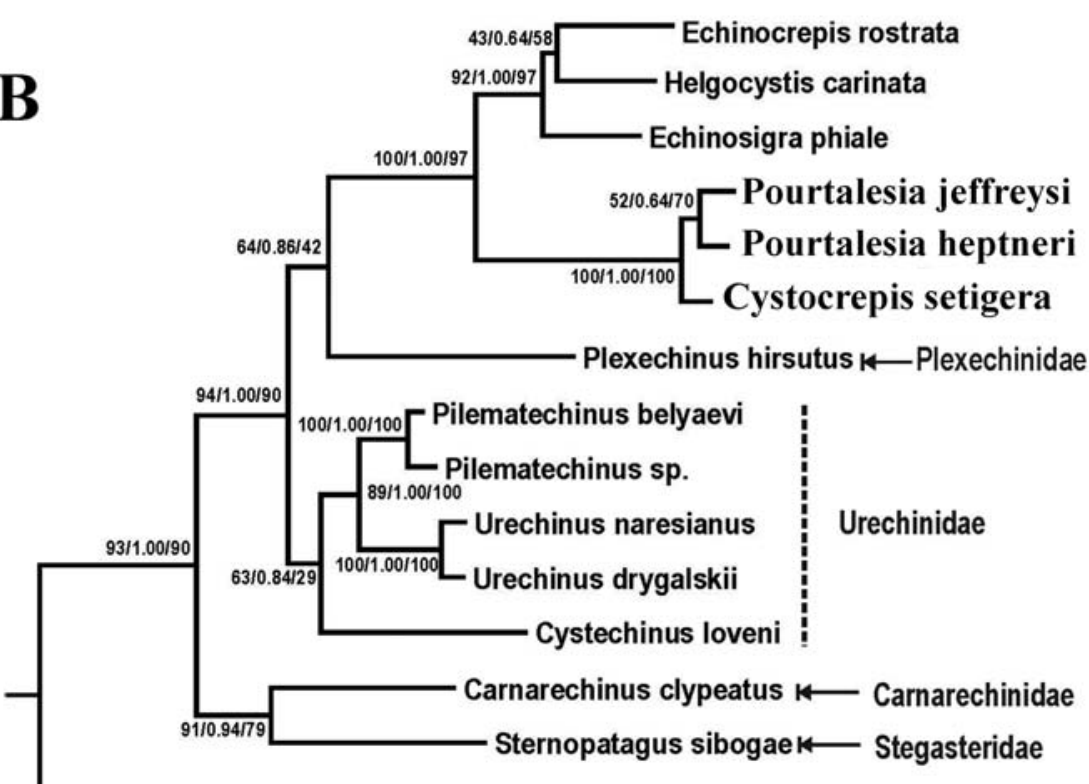

Echinocardium cordatum

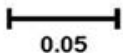


land Seas, north of Chukchi Sea, 830-3474 m). Thus, the genus shows a classical deep-sea distribution with records on the shelf or upper slope only in high latitudes in both hemispheres.

Elpidia (22 species, 70-9735 m) is the most widely distributed and eurybathic genus in the family Elpidiidae. All records of Elpidia at depths $<1000 \mathrm{~m}$ are in the Arctic Ocean (minimum depth $70 \mathrm{~m}$ ) and the Southern Ocean (542 $\mathrm{m})$. Morphological data suggest dispersal of Elpidia through the North Atlantic into the Arctic Ocean (Belyaev, 1975; Gebruk, 1990). Cladistic analysis, based on morphological characters, supports this hypothesis and indicates the Arctic emergence with formation of the most shallow-water species in the family, Elpidia glacialis, occurring at depths from 70 to $610 \mathrm{~m}$ (Rogacheva, 2007; Budaeva, Rogacheva, 2013; Rogacheva et al., 2013).

One and the same genera emerge both in the Arctic and the North Atlantic. For example, Pourtalesia ascends to $1160 \mathrm{~m}$ in the North Atlantic and $220 \mathrm{~m}$ in the Arctic, Kolga - to $1484 \mathrm{~m}$ and $659 \mathrm{~m}$ respectively. The Arctic emergence is not characteristic of small genera. Kolga is a rare example.

\section{Arctic submergence}

In $22(24 \%)$ abyssal genera, the Arctic species (including records outside the Arctic Ocean) were found at greater depths than the non-Arctic species (Table 1). Among these genera, the following occur only in the Arctic abyssal: Oceanactis, Cryodesma, Saduria, Pseudomysis, Portlandia, Tylaster, Ophiopleura and Dendrodoa. Distribution patterns of the isopod $\mathrm{Sa}$ duria and the ascidian Dendrodoa suggest, with a high probability, the Arctic shelf origin of abyssal species.

The genus Dendrodoa includes six species distributed in the Northern Hemisphere. The only species not known in the Arctic, D. abbotti, occurs in the north-east Pacific from the intertidal to $12 \mathrm{~m}$ (Newberry, 1984). The only species in this genus occurring in the abyssal is the Arctic-boreal D. grossularia $(2340 \mathrm{~m}$, the northern Laptev Sea). All other records of this species were from depths 6-600 m (Sirenko et al., 2004).

The distribution of Saduria similar to Dendrodoa is limited to the Northern Hemisphere (Fig. 4). There are four species in this genus: two Arctic endemics, S. sibirica (0-90-?160 m) and $S$. megalura (1546-3127 m), the Arctic-North Atlantic S. sabini (3-2298 m) and widely distributed in brackish and fresh waters glacial relict $S$. entomon $(0.5-2681 \mathrm{~m})$. The relict nature of $S$. entomon has been discussed by Segerstråle (1957): this species is common in Arctic estuaries, the Baltic and Caspian Seas and various northern inland lakes. Recently S. entomon invaded the Black Sea (Kvach, 2009). Records of Saduria deeper than $2000 \mathrm{~m}$ are known from the Norwegian, Greenland, Amundsen and Canada Basins (Sars, 1886; Gurjanova, 1946a; Malyutina, Kussakin, 1996a; Brandt, 1997a; De Broy-

Fig. 3. As example of Arctic emergence, the echinoid genus Pourtalesia.

A - bathymetric distribution of species of Cystocrepis and Pourtalesia; right bar — bathymetric range of the Arctic endemic $P$. jeffreysi; triple bar - bathymetric range of three closely related Atlantic species, now all recognised as $P$. miranda.

$\mathrm{B}$ - consensus phylogenetic tree of the order Holasteroida based on COI, 16S and 12S sequences inferred from MP, BI and ML analyses with Echinocardium cordatum (order Spatangoida) as the outgroup. Numbers by nodes indicate bootstrap supports for corresponding clades. P. heptneri is the deepest species $(5500-7340 \mathrm{~m})$ and $P$. feffreysi is the shallowest species $(220-3081 \mathrm{~m})$ in the genus. After Petrov et al. (2012).

Рис. 3. Пример арктической эмергенции, морские ежи рода Pourtalesia.

A — вертикальное распространение видов Cystocrepis и Pourtalesia; самый правый столбик - батиметрический диапазон арктического эндемика P. jeffreysi; тройной столбик - батиметрический диапазон трех близко родственных видов в Атлантике, объединенных под видовым названием P. miranda.

В - филогенетическое дерево отряда Holasteroida, основанное на объединенных нуклеодитных последовательностях 16S, 12S и COI, полученных с помощью MP, BI и ML анализов, с Echinocardium cordatum (отряд Spatangoida) в качестве внешней группы. Цифры при узлах указывают поддержку для соответствующих клад. P. heptneri является наиболее глубоководным видом (5500-7340 м), и P. feffreysi - наиболее мелководный вид (220-3081 м) в роде. По Петрову и др., (2012). 


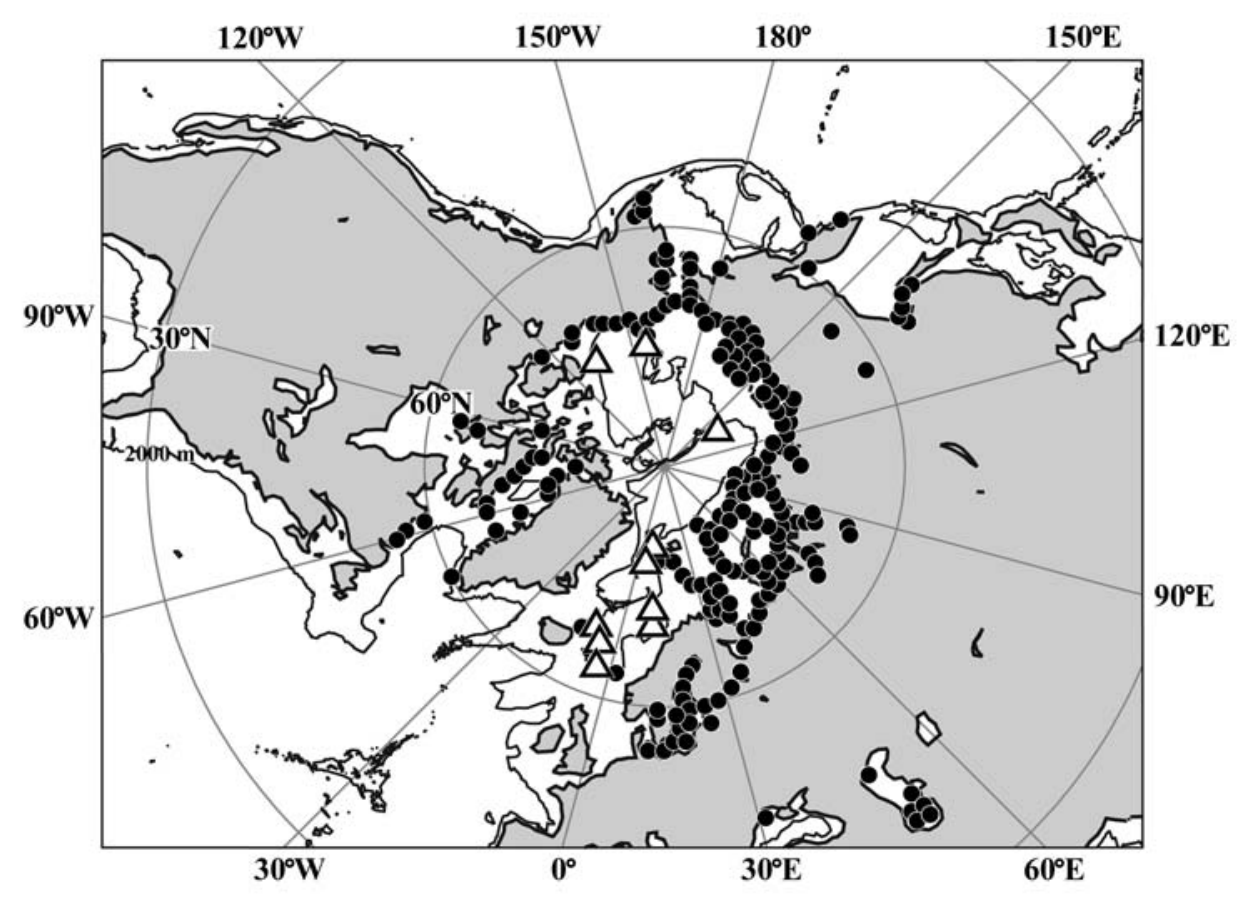

Fig. 4. Example of the distribution of an abyssal genus with an Arctic shelf origin: distribution of isopods of the genus Saduria; circles - records $<2000$ m; triangles — abyssal records ( $>2000$ m). After Ekman (1953) and Guryanova (1985b) with additions.

Рис. 4. Пример распространения рода, абиссальная фауна которого имеет арктическое шельфовое происхождение: распространение изопод рода Saduria; кружочки - нахождения на глубинах менее 2000 м; треугольники - нахождения в абиссали (>2000 м). По Ekman (1953) и Гурьяновой (1985b) с добавлениями.

er, Martin, 2004; Bergman et al., 2009; MacDonald et al., 2010). Morphological data suggest the shallow-water origin of the deep-sea endemic S. megalura (Gurjanova, 1946b, 1970). Both Dendrodoa and Saduria occur in a wide range of habitats. D. grossularia is known from wave-washed vertical infralittoral rocks to abyssal plains. S. entomon occurs from inland lakes to abyssal plains.

Fewer abyssal genera show Arctic submergence compared to Arctic emergence. The Arctic submergence is well pronounced only in two genera $(2 \%)$ out of the 92 genera considered, whereas Arctic emergence is highly possible for 12 genera (13\%). However, the share of genera with an Arctic submergence pattern substantially changes depending on taxon: from $0 \%$ (e.g. Echinoidea, Crinoidea, Holothuroidea) to about
$25 \%$ (Amphipoda). The amphipod fauna is characterized by probably the highest percentage of genera with submergence from the Arctic shelf to the abyssal. At least 64 genera of Amphipoda are known in the Arctic abyssal. This list is most probably incomplete. Distribution patterns suggest an Arctic shelf origin of abyssal species in at least 16 genera (Table 2). Distribution patterns of these genera (except for Ischyrocerus) are similar to those in Saduria and Dendrodoa. Genera of presumably the shelf origin occur on the shelf both in the Arctic and outside it but are found in the abyssal only in the Arctic Ocean (except for Ischyrocerus). They are not known from the Southern Hemisphere (except for $I s-$ chyrocerus, Haliragoides and Tmetonyx) but a half or most of their species occur in the Arctic (except for Ischyrocerus and Metacaprella). 
The genus Ischyrocerus deserves special attention. The distribution pattern of this genus suggests the Arctic shelf origin of abyssal species, despite the cosmopolitan distribution of the genus and occurrence in the abyssal outside the Arctic. The centre of species diversity is in the Arctic (17 species) and the North Pacific (18 species). The difference between tropical and northern species is so pronounced that Myers (1997) suggested splitting the genus. Among 17 Arctic species of Ischyrocerus, three occur in the Arctic abyssal. There is only one record of the genus in the abyssal outside the Arctic: $I$. hortatory was found off Isla de Chiloe (Chile) at $2454 \mathrm{~m}$.

Genera listed in Table 2, similar to Saduria and Dendrodoa, are characterized by high adaptability. Representatives of these genera inhabit all the main types habitats found in the Arctic: marine and brackish-water, benthic and pelagic, algal beds, intertidal rocks and fine deep-sea silts. There are also commensals among these genera. Species of Onisimus and Apherusa together with other amphipods dominate the iceassociated (sympagic) fauna (Melnikov, 1997; Gradinger, Bluhm, 2004; Arndt, Pavlova, 2005; Macnaughton et al., 2007; Nygård, 2011). Various habitats of only one species, Ischyrocerus anguipes, common in intertidal and upper subtidal zones of northern regions include intertidal rocks at high tide (Ingólfsson, Agnarsson, 2003), medium and coarse sand, pebble (Vallet, Dauvin, 1995), laminarian beds (Ryźycki, Gruszcyńsky, 1986), macroalgal rafts (Thiel, Gutow, 2005), estuaries (Ardisson, Bourget, 1992; Anisimova, 2000) and biotopes beneath the ice (Arndt, Swadling, 2006). This species also was recorded as a symbiont of invading species. Thus, I. anguipes was reported as a symbiont of the red king crab $P$. camtschaticus shortly after the latter appeared in the Barents Sea (Dvoretsky, Dvoretsky, 2009). In the North Pacific I. anguipes is known in association with the invaded brown seaweed Sargassun muticum (Norton, Benson, 1983).

For some genera (e.g. the amphipods Amphilochopsis, Centromedon, Dulichiopsis and Unciola) it is difficult to elucidate the region (the Arctic or North Atlantic) where the primary descent to the abyssal took place: some abyssal records belong both to the Arctic and the northern Atlantic close to the boundary between the Arctic and the Atlantic. Abyssal records of some, mostly shallow-water, genera (e.g. the amphipods Leptophoxus, Metopa and Plesymtes and the isopods Ananthura and Calathura) are known only from the boundary zone between the Arctic and the Atlantic, including areas of the Davis Strait, south of Greenland, south and south-west of Iceland (Fig. 5).

The amphipods of the Themisto genus were considered as mainly epipelagic, although some specimens have been recorded at depths 2000$3000 \mathrm{~m}$ (Vinogradov et al., 1982). Bulycheva (1964) reported Themisto abyssorum, T. compressa (the junior synonim of the Antarctic $T$. gaudichaudii) and T. libellula from the Arctic Ocean deeper than $2000 \mathrm{~m}$ (down to 3000 or $3100 \mathrm{~m}$ ). Dense near-bottom populations of $T$. abyssorum (mainly the near-adult females) were observed on dives of the Mir submersibles in the Norwegian Sea at 1200-1700 m (Vinogradov, 1999). Bulycheva (1964) suggesed that T. compressa drifts with the Gulf Stream from the North Atlantic to the Central Arctic and the Barents Sea. If so, T. compressa in the Arctic may occasionally descend from shallow waters to the deep-sea.

Genera characterized by Arctic submergence have penetrated the Arctic shelf from the shelf of the North Atlantic or North Pacific. The first pathway seems to be common for most genera. Only in Arrhis, Ischyrocerus and Metacaprella do most species occur in the North Pacific. Therefore, it is most likely that they have dispersed from the North Pacific shelf.

The biogeographical history of the Arctic Ocean is characterized by active processes of emergence and submergence. Perhaps only the Southern Ocean is comparable with the Arctic in intensity of evolutionary emergence and submergence of fauna. Some authors suggest (Gurjanova, 1939, 1957; Koltun, 1964; Nesis, 1983, 2001; Svavarsson et al., 1993; Clarke, 2003) that part of shallow-water Arctic fauna survived during the glaciation owing to migration to the 


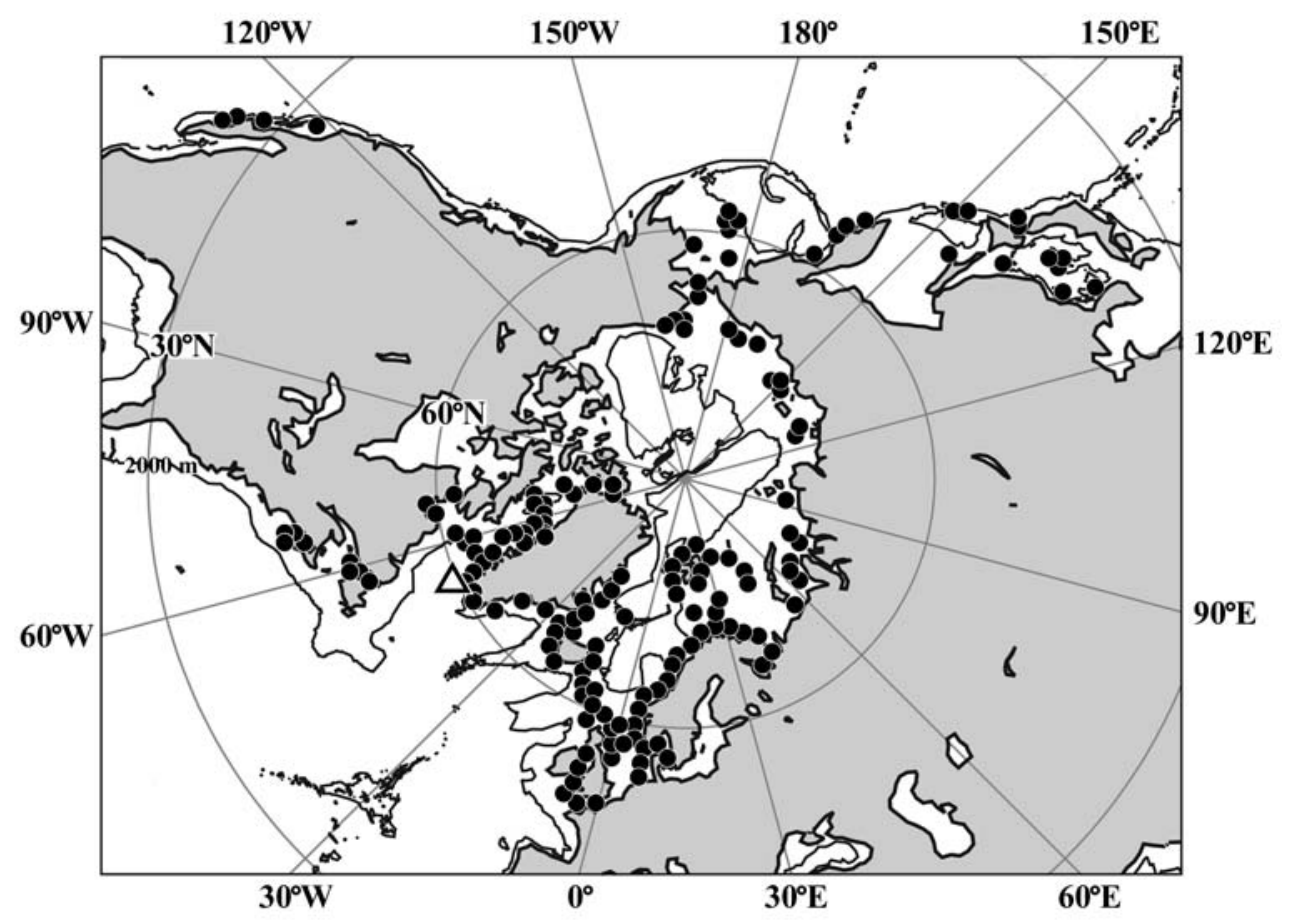

Fig. 5. Distribution of amphipods of the genus Metopa. A single abyssal record is in the transition zone between the arctic and boreal faunas. Circles — records $<2000 \mathrm{~m}$, triangle — abyssal record (3521 m). After Tandberg (2011) with additions.

Рис. 5. Распространение амфипод рода Metopa. Единственное нахождение в абиссали расположено в переходной зоне между арктической и бореальной фаунами. Кружочки - нахождения на глубинах менее 2000 м, треугольник — нахождение в абиссали (3521 м). По Tandberg (2011) с добавлениями.

Arctic Ocean depths. However, this hypothesis cannot explain the fact that together with submergence there was an active emergence of deep-sea fauna in the Arctic Ocean. Besides, the increase of extent and thickness of the ice sheet during periods of glaciation should have led to depression of both shallow-water and deep-sea faunas: surface productivity declined and water stratification intensified resulting in decline of organic matter and oxygen at depths.

The Arctic submergence and emergence are apparently caused by the same factors: the similarity of shallow-water and deep-sea environments in the Arctic Ocean and the young age of the modern Arctic environment (and Arctic biotic complexes). If so, the emergence and submergence occurred in the Arctic simultaneously and followed similar scenarios. The Arctic fauna was depressed during glaciations, resulting in a decrease of species diversity and destruction of the biotic complexes. The postglacial warming stimulated dispersal of deepsea and shallow-water species into the Arctic Ocean from the donor regions, the North Atlantic and the North Pacific. The deep-sea and shallow-water environments in the Arctic are less different than in the donor regions. This can stimulate dispersal both from and to the deep. In addition, the pre-glacial biotic complexes of the Arctic Ocean were destroyed and barriers to dispersal became more easily permeable (Mironov, 2013). As a result, some deep-sea genera dispersed to shallow waters (the Arctic emergence), whereas other genera dispersed from shallow waters to the deep (the Arctic submergence). 


\section{Acknowledgements}

We are grateful for advices on the abyssal species distribution to the following experts: N. Sanamyan (Actiniaria), K. Sanamyan (Ascidia), M. Malyutina (Isopoda), G.M. Vinogradov, and O.E Kamenskaya (Amphipoda), A.V. Gebruk (Holothurioidea). This work is part of the project "Arctic marine fauna: data accumulated in Russia" (sub-project of the CoML “Arctic Ocean Diversity” program).

\section{References}

Afanasjev I.F., Filatova Z.A. 1980. [On the studies of deep-water benthic fauna of the Canada Basin of the Arctic Ocean] // M.E. Vinogradov, I.A. Melnikov (eds.). [Biology of the Central Arctic Ocean]. Moscow: Nauka Press. P.219-229 [in Russian].

Anisimova N.A. 2000. [Crustaceans of the bays and gulfs on the southern part of the Pechora and the Kara seas] // G.G. Matishov (ed.). [Current Benthos of the Barents and the Kara seas]. Apatity: Kola Science Centre RAS. P.115-156 [in Russian].

Andriashev A.P. 1985. [Sea fishes] // A.F. Treshnikov, (ed). [Atlas of the Arctic]. Moscow: Main Department of geodesy and cartography of the Council of Ministers USSR. P.187 [in Russian].

Appeltans W., Bouchet P., Boxshall G.A., De Broyer C., de Voogd N.J., Gordon D.P., Hoeksema B.W., Horton T., Kennedy M., Mees J., Poore G.C.B., Read G., Stöhr S., Walter T.C., Costello M.J. (eds.). 2012. World Register of Marine Species. Accessed at http:// www.marinespecies.org on 2013-06-03.

Ardisson P.-L., Bourget E. 1992. Large-scale ecological patterns: discontinuous distribution of marine benthic epifauna // Marine Ecology Progress Series. Vol.83. P.15-34.

Arndt C.E., Pavlova O. 2005. Origin and fate of ice fauna in the Fram Strait-Svalbard area // Marine Ecology Progress Series. Vol.301. P.55-66.

Arndt C.E., Swadling K.M. 2006. Crustacea in Arctic and Antarctic sea ice: distribution, diet and life history strategies // Advances in Marine Biology. Vol.59. P.198-315.

Baranova Z.I. 1964. [Echinodermata, collected on an expedition on the ice-breaker "F.Litke" in 1955] // Trudy Arkticheskogo i Antarkticheskogo nauchnoissledovatel'skogo Instituta [Proceedings of Arctic and Antarctic Institute]. Vol.259. P.355-372 [in Russian].

Barnard J.L., Menzies R.J., Bacescu M.C. 1962. Abyssal Crustacea. New York and London: Columbia University Press. 233 p.

Beklemishev K.V., Semina H.J. 1986. [Geography of planktonic diatoms of high and temperate latitudes of the ocean] // P.A. Moiseyev (ed.). [Biotopic basis of distribution of marine organisms]. Moscow: Nauka. P.7-23 [in Russian].

Belyaev G.M. 1975. [New holothurians species of the genus Elpidia from the southern part of the Atlantic
Ocean] // Trudy Instituta Okeanologii AN SSSR [Transactions of the P.P. Shirshov Institute of oceanology]. Vol.103. P.259-279 [in Russian, English abstract].

Belyaev G. M., Mironov A. N. 1981. [New species of the genus Acanthotrochus (Apoda, Myriotrochidae)] // Zoologicheskii Zhurnal [Russian Journal of Zoology]. Vol.60. No.4. P.520-529 [in Russian, English abstract].

Bergmann M., Dannheim J., Bauerfeind E., Klages M. 2009. Trophic relationships along a bathymetric gradient at the deep-sea observatory HAUSGARTEN // Deep-Sea Research I. Vol.56. No.3. P.408-424.

Bernard F.R. 1979. Bivalve mollusks of the Western Beaufort Sea // Contributions in Science, Natural History Museum of Los Angeles County. Vol.313. P. $1-80$.

Bluhm A. B., Ambrose W.G. Jr., Bergmann M., Clough L.M., Gebruk A.V., Hasemann C., Iken K., Klages M., MacDonald I.R., Renaud P.E., Schewe I., Soltwedel T., Włodarska-Kowalczuk M. 2011. Diversity of the arctic deep-sea benthos // Marine Biodiversity. Vol.41. No.1. P.87-107.

Bouchet P., Warén A. 1979. The abyssal molluscan fauna of the Norwegian Sea and its relation to other faunas // Sarsia. Vol.64. P.211-243.

Brandt A. 1997. Abundance, diversity and community patterns of epibenthic- and benthic-boundary layer peracarid crustaceans at $75^{\circ} \mathrm{N}$ off East Greenland // Polar Biology. Vol.17. P.159-174.

Brandt A. 2005. Isopoda of the European North Atlantic from depths exceeding $2000 \mathrm{~m}$, excluding Epicaridea. Mitteilungen aus dem Hamburgischen zoologischen Museum and Institut. Vol.102. S.179-190.

Brandt A., Błażewicz-Paszkowycz M., Bamber R., Mühlenhardt-Siegel U., Malyutina M., Kaiser S., De Broyer C., Havermans C. 2012. Are there widespread peracarid species in the deep sea (Crustacea: Malacostraca)? // Polish Polar Research. Vol.33. No.2. P.139162.

Brix S., Svavarsson J. 2010. Distribution and diversity of desmosomatid and nannoniscid isopods (Crustacea) on the Greenland-Iceland-Faeroe Ridge // Polar Biology. Vol.33. P.515-530.

Broch H. 1953. Cirripedia Thoracica // The Danish IngolfExpedition. Vol.3. No.14. P.1-16.

Budaeva N.E., Mokievsky V.O., Soltwedel T., Gebruk A.V. 2008. Horizontal distribution patterns in Arctic macrobenthic deep-sea communities // Deep-Sea research part I, Oceanographic research papers. Vol.55. P.1167-1178.

Budaeva N.E., Rogacheva A.V. 2013. Colonization of the Arctic Ocean by two cosmopolitan genera of marine invertebrates // Invertebrate Zoology. Vol.10. No.1. P.127-142.

Bulycheva A.I. 1964. [Hyperiids (Amphipoda-Hyperiidea) of Arctic Seas] // Trudy Arcticheskogo i Antarkticheskogo Nauchno-Issledovatelskogo Instituta [Proceedings of the Arctic and Antarctic Science Research Institute]. Vol.259. P.316-321 [in Russian].

Carlgren O. 1913. Zoantharia // The Danish Ingolf Expedition. Vol.5. Pt.4. P.1-65. 
Carlgren O. 1942. Actiniaria II // The Danish Ingolf Expedition. Vol.5. Pt.12. P.1-92.

Clark A.M. 1970. Echinodermata, Crionoidea // Marine Invertebrates of Scandinavia. Vol.3. P.1-55.

Clark A.M. 1989. An index of names of recent Asteroidea. Part 1: Paxillosida and Notomyotida // Echinoderm Studies. Vol.3. P.225-347.

Clark A.M. 1993. An index of names of recent Asteroidea. Part 2: Valvatida// Echinoderm Studies. Vol.4. P.187366.

Clark A.M. 1996. An index of names of Recent Asteroidea. Part 3: Velatida and Spinulosida // Echinoderm Studies. Vol.5. P.183-250.

Clark A.M., Mah C. 2001. An index of names of Recent Asteroidea. Part 4: Forcipulatida and Brisingida // Echinoderm Studies. Vol.6. P. 229-347.

Clarke A. 2003. The polar deep seas // P.A. Tyler (ed.). Ecosystems of the World. Vol.28. Ecosystems of the deep oceans. Amsterdam, The Netherlands: Elsevier. P.239-260.

Coan E.V., Scott P.V., Bernard F.R. 2000. Bivalve seashells of western North America // Santa Barbara Museum of Natural History. Monographs 2. P.1-764.

Dahl E. 1979. Amphipoda Gammaridea from the deep Norwegian Sea. A preliminary report// Sarsia. Vol.64. P.57-60.

Danielssen D.C. 1890. Actinida // Den Norske NordhavsExpedition 1876-1878. Zoologi. Vol.19. P.1-184.

Danielssen D.C., Koren J. 1877. Fra den Norske Nordhavs Expedition: Echinodermer// Nyt Magazin for Naturvidenskaberne. Vol.23. No.3. P.45-83.

Danielssen D.C., Koren J. 1884. Asteroidea // Den Norske Nordhavs Expedition 1876-1878. Zoologi. Vol.11. P.1-119.

De Broyer C., Martin P. 2004. Biodiversity, molecular phylogeny and trophic ecology of amphipod crustaceans in the polar deep sea: a bipolar comparison // Berichte zur Polar- und Meeresforshung. Vol.488. P.281-285.

Derjugin K.M. 1915. [The fauna of Kola Bay and the conditions of its existence] // Zapiski Imperatorskoy Academii Nauk. Seria 8. Fiziko-Matematicheskiy Otdel. Vol.34. No.1. P.1-929 [in Russian].

Deubel H. 2000. Struktureigenschaften und Nahrungsbedarf der Zoobenthosgemeinschaften im Bereich des Lomonossowrückens im Arktischen Ozean // Berichte zur Polarforschung. Bd.370. S.1-147.

Djakonov A.M. 1950. [Asteroidea of the Seas of the USSR] // Opredeliteli po faune SSSR [Keys to the fauna of the USSR]. Vol.34. P.1-212 [in Russian].

Djakonov A.M. 1954. [Ophiuroidea of the Seas of the USSR] // Opredeliteli po faune SSSR [Keys to the fauna of the USSR]. Vol.55. P.1-136 [in Russian; English translation: 1967. Jerusalem, 123 p.]

Dvoretsky A.G., Dvoretsky V.G. 2009. Some aspects of the biology of the amphipods Ischyrocerus anguipes associated with the red king crab, Paralithodes camtschaticus, in the Barents Sea // Polar Biology. Vol.32. P.463-469.

Ekman S.1953. Zoogeography of the sea. London: Sidgwick and Jackson. 417 p.

Eléaume M., Bohn J.-M., Roux M., Améziane N. 2012. Stalked crinoids (Echinodermata) collected by the R/ $\mathrm{V}$ Polarstern and Meteor in the south Atlantic and in Antarctica // Zootaxa. Vol.3425. P.1-22.
England J.H., Fueze M.F.A. 2008. New evidence from the western Canadian Arctic Archipelago for the resubmergence of the Bering Strait // Quaternary research. Vol.70. No.1. P.60-67.

Fautin D.G. 2008. Hexacorallians of the World. Available from: http://geoportal.kgs.ku.edu/hexacoral/anemone2/ index.cfm.

Filatova Z.A. 1951. [Some zoogeographical patterns of the bivalve mollusks from the genus Portlandia] // Trudy Instituta okeanologii [Transactions of the Institute of Oceanology]. Vol.6. P.117-131 [In Russian].

Filatova Z.A. 1962. Bivalve molluscs of the Northern seas of Eurasia and the zoogeographical division of the Arctic // Proceedings of the 1st European Malacological. Congress, London, 1962. London: Conchological Society of Great Britain and Ireland and the Malacological Society of London. P.37-43.

Filatova Z., Zenkevitch L. 1957. [Quantitative distribution of the fauna in the Kara Sea] // Trudy Vsesoyuznogo Okeanologicheskogo Obschestva. Vol.8. P.3-67 [in Russian].

Gebruk A.V. 1990. [Deep-sea holothurians of Elpidiidae family]. Moscow: Nauka, 160 p. [in Russian].

Gebruk A.V. 1994. Two main stages in the evolution of the deep-sea fauna of elasipoid holothurians // B. David, A. Guille, J.-P. Féral, M. Roux (eds.). Echinoderms through Time. Rotterdam: Balkema. P.507-514.

Gebruk A.V., Rogacheva A.V. 2010. Evolutionary relationships in trench species of the genus Elpidia // Trench Connection Symposium, 10-13 November 2010. Abstracts of Oral Presentations. Tokyo: the University of Tokyo. P.20.

Golikov A.N., Scarlato O.A. 1989. Evolution of Arctic ecosystem during the Neogene period // Y. Herman (ed.). The Arctic Seas. New York: Van Nostrand. P.257-279.

Gorbunov G.P. 1946. [Bottom life of the Novosiberian shoalwaters and the central part of the Arctic Ocean] // Trudy dreifuyustchei ekspeditsii Glavsevmorputi na ledokolnom parohode "G. Sedov" 1937-1940 [Transactions of the Drifting expedition of Glavsevmorput on the ice-breaker "G. Sedov" 1937-1940]. Vol.3. P.30-138 [in Russian with English summary].

Gradinger R.R., Bluhm B.A. 2004. In-situ observations on the distribution and behavior of amphipods and Arctic cod (Boreogadus saida) under the sea ice of the High Arctic Canada Basin // Polar Biology. Vol.27. P.595-603.

Gurjanova E. 1938. [On the question of the composition and origin of the abyssal fauna of the Polar Basin] // Doklady Akademii Nauk SSSR [Comp. Rend. Acad. Sci. URSS]. Vol.20. No.4. P.333-336 [in Russian].

Gurjanova E.F. 1939. [Contribution to the origin and history of the fauna of the Polar Basin] // Izvestiya Akademii Nauk SSSR [Bulletin de l'Académie des Sciences de l'URSS. Classe des sciences bioloques]. Vol.5. P.679-704 [in Russian].

Gurjanova E. 1946a. [New species of Isopoda and Amphipoda from the Arctic Ocean] // Trudy dreifuyustchei ekspeditsii Glavsevmorputi na ledokolnom parokhode "G. Sedov" 1937-1940 [Transactions of the Drifting expedition of Glavsevmorput on the icebreaker "G. Sedov" 1937-1940]. Vol.3. P.272-297 [in Russian]. 
Gurjanova E. 1946b. [Individual and age variability of the marine assel and its importance in the evolution of the genus Mesidothea Rich.] // Trudy Zoologischeskogo Instituta, Akademiya Nauk SSSR [Transactions of the Zoological Institute]. Vol.8. P.105144 [in Russian].

Gurjanova E.F. 1951. [Side-swimmers of the Seas of the USSR and adjacent waters (Amphipoda-Gammaridea)] // Opredeliteli po faune SSSR [Keys to the fauna of the USSR]. Vol.41. P.1-1029 [in Russian].

Gurjanova E.F. 1957. [Towards zoogeography of the Arctic Basin] // [Materials of scientific research drifting station "Severnii Polus-3" and "Severnii Polus-4" 1954/55 years]. Vol.1. P.343-355 [in Russian].

Gurjanova E.F. 1964. [Amphipod and isopod fauna in the near-Atlantic depression of the Arctic Basin (Nansen Basin)] // Trudy Arkticheskogo i Antarkticheskogo nauchno-issledovatelskogo Instituta [Proceedings of Institute of Arctic and Antarctic Scientific Investigations of the Central Board of the Hydrometeorological Service for the Council of Ministers of the USSR]. Vol.59. P.255-314 [in Russian].

Gurjanova E.F. 1970. [Peculiarities of the Arctic Ocean fauna and their importance for understanding the history of its origin] // [The Arctic Ocean and its coast in the Cenozoic]. Leningrad: Gidrometeoizdat. P.126161 [in Russian].

Gurjanova E.F. 1985a. [Benthos] // A.F. Treshnikov(ed.). [Atlas of the Arctic]. Moscow: Main Department of geodesy and cartography of the Council of Ministers USSR. P.186 [in Russian].

Gurjanova E.F. 1985b. [Map XI. 17. Deep water species of Arctic endemic genera of echinoderms and species of autochtonic arctic isopod genus] // A.F. Treshnikov (ed.). [Atlas of the Arctic]. Moscow: Main Department of geodesy and cartography of the Council of Ministers USSR. P.131.

Häcker V. 1904. Bericht über die Tripyleen-Ausbeute der Deutschen Tiefsee-Expedition // Verhandlungen der Deutschen Zoologischen Gesellschaft. Bd.14. S.122-157.

Haedrich R.L., Krefft G. 1978. Distribution of bottom fishes in the Denmark Strait and Irmiger Sea // DeepSea Research. Vol.25. P.705-720.

Hansen H.J. 1916. Crustacea Malacostraca III. The order Isopoda // Danish Ingolf Expedition. Vol.3. Pt.5. P.1-262.

Hartmeyer R. 1923. Ascidiacea. Part 1: Zugleich eine Übersicht über die arktische und boreale Ascidienfauna auf tiergeographischer Grundlage // Danish Ingolf Expedition. Bd.2. T.6. S.1-368.

Hess H. 2011. Isocrinida // P.A. Selden et al. (eds.). Treatise on Invertebrate Paleontology. Part T. Echinodermata 2, Revised Crinoidea. Vol. 3. Lawrence, Kansas: The University of Kansas Paleontological Institute. P.42-69.

Hessler R.R. 1970. The Desmosomatidae (Isopoda, Asselota) of the Gay Head-Bermuda transect // Bulletin of the Scripps Institution of Oceanography, University of California, San Diego. Vol.15. P.1-185.

Hessler R.R., Wilson G.D.F., Thistle D. 1979. The deepsea isopods: a biogeographic and phylogenetic overview // Sarsia. Vol.64. P.67-76.

Hessler R.R., Thistle D. 1975. On the place of origin of deepsea isopods // Marine Biology. Vol.32. P.155-165.
Ingólfsson A., Agnarsson I. 2003. Amphipods and isopods in the rocky intertidal: dispersal and movements during high tide // Marine Biology. Vol.143. P.859-866.

Ivanov D.L., Zarubina E.M. 2004. Distribution of scaphopod molluscs (Mollusca, Scaphopoda) in the North Atlantic and Arctic oceans, based on materials of Russian and Soviet expeditions // Ruthenica. Vol.14. No.1. P.89-104.

Jensen P. 1992. Cerianthus vogti Danielssen, 1890 (Anthozoa: Ceriantharia). A species inhabiting an extended tube system deeply buried in deep-sea sediments off Norway // Sarsia. Vol.77. P.75-80.

Jirkov I.A. 2001. [Polychaeta of the Arctic Ocean]. Moscow: Yanus-K Press. 632 p. [in Russian].

Just J. 1970. Decapoda, Mysidacea, Isopoda and Tanaidacea from Jørgen Brønlund Fjord, North Greenland // Meddelelser om Grønland udgivne af Kommissionen for Viderskabelige Undersøgelser i Grønland. Vol.184. No.9. P.1-32.

Just J. 1980a. Polar Sea abyssal and deep bathyal Isopoda (Crustacea) // Steenstrupia. Vol.6. No.14. P.197-230.

Just J. 1980b. Abyssal and deep bathyal Malacostraca (Crustacea) from the Polar Sea // Videnskabelige Meddelelser fra Dansk naturhistorisk Forening. Vol.142. P.161-177.

Kafanov A.I. 1979. [About the status of the Arctic marine biogeographical province (according to paleontological data)] // Paleoekologiya soobshchestv morskikh bespozvonochnykh [Paleoecology of marine invertebrate assemblages]. Vladivostok: DVNTs AN SSSR. P.100-128 [in Russian].

Kamenskaya O.E. 2001. [Deep-sea amphipods from the collections of the drifting station 'North Pole-22' with some remarks on morphology, feeding and ecological groups] // A.P. Kuznetsov, O.N Zezina (eds.). [Composition and structure of the marine bottom biota]. Moscow: VNIRO Publishing House. P. 159-163, 169 [in Russian].

Keuning R., Schander C. 2010. Thyasira ockelmanni (Mollusca: Bivalvia: Veneroidea), a new species of Thyasiridae from the Norwegian Sea // Fauna Norvegica. Vol.30. P.21-24.

Klikushin V.G. 1977. [Sea-lilies of the genus Isselicrinus] // Paleontologicheskii Zhurnal [Paleontological Journal]. Vol.1. P.87-95 [in Russian].

Klikushin V.G. 1992. [Fossil pentacrinid crinoids and their distribution in the USSR]. Leningrad: Leningrad Paleontological Laboratory. 358 p. [in Russian].

Knudsen J. 1985. Abyssal Mollusca of the Arctic Ocean // Journal of Conchology. Vol.32. No.2. P.1-97.

Koltun V.M. 1964. [To studies of benthic fauna of the Greenland Sea and central part of the Arctic Basin] // Trudy Arcticheskogo i Antarkticheskogo NauchnoIssledovatelskogo Instituta [Proceedings of the Arctic and Antarctic Science Research Institute]. Vol.259. P.13-78 [in Russian].

Kosobokova K. 2010. [Zooplankton of the Arctic Basin: structure of the communities and regional quantitative distribution patterns]. Doctor of Sciences Dissertation. Moscow: Institute of Oceanology. 316 p. [in Russian].

Kröncke I. 1994. Macrobenthos composition, abundance and biomass in the Arctic Ocean along a transect 
between Svalbard and the Makarov Basin // Polar Biology. Vol.14. P.519-529.

Krylova E.M., Ivanov D.L., Mironov A.N. 2013. The ratio of species of Atlantic and Pacific origin in modern Arctic fauna of bivalve molluscs // Invertebrate Zoology. Vol.10. No.1. P.89-126.

Krylova E.M., Gebruk A.V., Portnova D.A., Todt C., Haflidason H. 2011. New species of the genus Isorropodon (Bivalvia, Vesicomyidae, Pliocardiinae) from methane seeps at Nyegga (Norwegian Sea, Vøring Plateau, Storrega slide) // Journal of the Marine Biological Association. Vol.91. No.5. P.1135-1144.

Krylova E.M., Sahling H. 2010. Vesicomyidae (Bivalvia): current taxonomy and distribution // PLoS ONE. Vol.5. No.4. P.1-9.

Kussakin O.G. 1979. [Marine and brackish-water Isopoda of the cold and temperate waters of the Northern Hemisphere. I. Suborder Flabellifera] // Opredeliteli po faune SSSR [Keys to the fauna U.S.S.R.]. Vol.122. P.1-472 [in Russian].

Kussakin O.G. 1982. [Marine and brackish-water Isopoda of the cold and temperate waters of the Northern Hemisphere. II. Suborders Anthuridea, Microcerberidea, Valvifera and Tyloidea] // Opredeliteli po faune SSSR [Keys to the fauna U.S.S.R.]. Vol.131. P.1-464 [in Russian].

Kussakin O.G. 1988. [Marine and brackish-water Isopoda of the cold and temperate waters of the Northern Hemisphere. III. Suborder Asellota. Part 1] // Opredeliteli po faune SSSR [Keys to the fauna U.S.S.R.]. Vol.152. P.1-502 [in Russian].

Kussakin O.G. 1999. [Marine and brackish-water Isopoda of the cold and temperate waters of the Northern Hemisphere. III. Suborder Asellota. Part 2] // Opredeliteli po faune SSSR [Keys to the fauna U.S.S.R.]. Vol.169. P.1-385 [In Russian].

Kussakin O.G. 2003. [Marine and brackish-water Isopoda of the cold and temperate waters of the Northern Hemisphere. III. Suborder Asellota. Part 3] // Opredeliteli po faune SSSR [Keys to the fauna U.S.S.R.]. Vol.171. P.1-381 [in Russian].

Kvach Y. 2009. First report of Saduria (Mesidothea) entomon (Linnaeus, 1758) (Isopoda: Chaetiliidae) in the Black Sea // Aquatic Invasions. Vol.4. No.2. P.393-395.

Larsen K. 1998. Caprellidea (Crustacea: Amphipoda) from Faroe Islands waters, with a key to the North-Atlantic species // Faroes Journal of Arts and Sciences. Vol.46. P.81-90.

Leontjev O.K. 1985. [Morphometry] // A.F. Treshnikov, S.S. Sal'nikov (eds.). [The Arctic and Southern Oceans]. Leningrad: Nauka. P.17-18 [in Russian].

Lomakina N.B. 1964. [Mysids, cumaceans and euphausiids (Mysidacea, Cumacea et Euphausiacea) in the materials of the Arctic expedition on RV "F. Litke" 1955, RV “Ob” 1956 and RV “Lena" 1957 and 1958] // Trudy Arcticheskogo i Antarkticheskogo NauchnoIssledovatelskogo Instituta [Proceedings of the Arctic and Antarctic Science Research Institute]. Vol.259. P.241-254 [in Russian].

MacDonald I.R., Bluhm B.A., Iken R., Gagaev S., Strong S. 2010. Benthic macrofauna and megafauna assemblages in the Arctic deep-sea Canada Basin // Deep Sea Research, Part II. Vol.57. No.1-2. P.136-152.
Madsen F.J., Hansen B. 1994. Echinodermata, Holothurioidea // Marine Invertebrata of Scandinavia. Vol.9. P.1-143.

Malyutina M.V., Kussakin O.G. 1996a. Addition to the Polar Sea bathyal and abyssal Isopoda (Crustacea). Part I. Anthuridea, Valvifera, Asellota (Ischnomesidae, Macrostylidae, Nannoniscidae)//Zoosystematica Rossica. Vol.4. No.1. P.49-62.

Malyutina M.V., Kussakin O.G. 1996b. Additions to the Polar Sea bathyal and abyssal Isopoda (Crustacea, Malacostraca). Part 2. Asellota: Desmosomatidae // Zoosystematica Rossica. Vol.4. No.2. P.239-260.

Malyutina M.V., Kussakin O.G. 1996c. Additions to the Polar Sea bathyal and abyssal Isopoda (Crustacea, Malacostraca). Part 3. Asellota: Munnopsidae // Zoosystematica Rossica. Vol.5. No.1. P.13-27.

Macnaughton M.O., Thormar J., Berge J. 2007. Sympagic amphipods in the Arctic pack ice: redescriptions of Eusirus holmii Hansen, 1887 and Pleusymtes karstensi (Barnard, 1959) // Polar Biology. Vol.30. No.10131025.

Melnikov I.A. 1997. The Arctic sea ice ecosystem. Amsterdam: Gordon \& Breach. 204 p.

Menzies R.J. 1963. The abyssal fauna of the sea floor of the Arctic Ocean // Proceedings of the Arctic Basin Symposium, Oct. 1962. Washington, D.C.: The Arctic Institute of North America. P.46-66.

Menzies R.J., George R.Y., Rowe G.T. 1973. Abyssal environment and ecology of the World Ocean. New York: John Wiley. 488 p.

Mezhov B. 1993. Three new species of Macrostylis G.O. Sars, 1864 (Crustacea Isopoda Asellota Macrostylidae) from the Pacific Ocean // Arthropoda Selecta. Vol.2. No.3. P.3-9.

Millar R.H. 1966.Tunicata. Ascidiacea // Marine Invertebrates of Scandinavia. Vol.1. P.1-123.

Minin K.V. 2012. Vertical trends in morphological variability of sea urchins of the genus Echinus from the Northeast Atlantic and Arctic // Paleontological Journal. Vol.46. No.8. P.927-935.

Minin K.V., Petrov N.B., Vladychenskaya I.P. 2012. Sea urchins of the genus Gracilechinus Fell \& Pawson, 1965 from the Pacific Ocean. Morphology, phylogeny and origin // Molecular Phylogenetics. Contributions of the $3^{\text {rd }}$ Moscow International Conference "Molecular Phylogenetics" (Molphy-3), July 31 - August 4, 2012. Moscow: Torus Press. P.121-122.

Mironov A.N. 1975. [Mode of life of the pourtalesiid seaurchins (Echinoidea: Pourtalesiidae)] // Trudy Instituta okeanologii [Transactions of the P.P. Shirshov Institute of oceanology]. Vol.103. P.281-288 [in Russian, English summary].

Mironov A.N.1980. [Two ways of formation of deep-sea echinoid fauna] // Okeanologia [Oceanology]. Vol.20. No.4. P.703-708 [in Russian, English summary].

Mironov A.N.1982. [Role of the Antarctic in the formation of deep-sea bottom fauna of the World Ocean] // Okeanologia [Oceanology]. Vol.22. No.3. P.486-491 [in Russian, English summary].

Mironov A.N. 1995. [Holasteroid echinoids. 2. Pourtalesia] // Zoologicheskii zhurnal [Russian Journal of Zoology]. Vol.74. No.12. P.59-75 [in Russian, English abstract]. 
Mironov A.N. 2006. Centers of Marine Fauna Redistribution. Entomological Review Vol. 86, Suppl.1. P.3244.

Mironov A.N. 2008. Pourtalesiid sea urchins (Echinodermata: Echinoidea) of the northern Mid-Atlantic Ridge // Marine Biology Research. Vol.4. No.1-2. P.3-24.

Mironov A.N. 2013. Biotic complexes of the Arctic Ocean // Invertebrate Zoology. Vol.10. No.1. P.3-48.

Monniot C., Monniot F. 1979. Tuniciers benthiques récoltés au cours de la campagne Norbi en mer de Norvège // Bulletin du Muséum national d'histoire naturelle. Paris. 4e sér. Vol.1. Section A(3). P.563-573.

Mortensen T. 1903. Echinoidea // The Danish IngolfExpedition. Vol.4. Pt.1. P.1-193.

Mortensen T. 1907. Echinoidea // The Danish IngolfExpedition. Vol.4. Pt.2. P.1-200.

Mortensen T. 1933. Ophiuroidea // The Danish Ingolf Expedition. Vol.4. Pt.8. P.1-121.

Murina G.V. 1977. [Marine sipunculid worms of arctic and boreal waters of Eurasian] // Opredeliteli po faune SSSR [Keys to the fauna of the USSR]. Vol.111. P.1283 [in Russian].

Murina V., Sørensen J. 2004. Marine worms of the phylum Sipuncula in Faroese waters // Fróðskaparrit. Vol.51. P.280-291.

Myers A.A. 1997. Amphipoda from the South Pacific: Western Samoa // Records of the Australian Museum. Vol.49. No.1. P.99-109.

Nesis K.N. 1965 Ecology of Cyrtodaria siliqua and history of the genus Cyrtodaria (Bivalvia: Hiatellidae) // Malacologia. Vol.3. P.197-210.

Nesis K.N. 1983. [Hypothesis on the cause of origin of western and eastern Arctic ranges of marine benthic animals] // Biologiya Morya [Russian Journal of Marine Biology]. Vol.5. P.3-13 [in Russian, English abstract].

Nesis K.N. 2001. West-Arctic and East-Arctic distributional ranges of cephalopods // Sarsia. Vol.86. P.1-11.

Newberry A.T. 1984. Dendrodoa (Styelopsis) abbotti, sp. nov. (Styelidae, Ascidiacea) from the Pacific coast of the United States, and its impact on some gonadal criteria of its genus and subgenus // Proceedings of the California Academy of Sciences. Vol.43. No.15. P.239-248.

Norton T.A., Benson M.R. 1983. Ecological interactions between the brown seaweed Sargassun muticum and its associated fauna // Marine Biology. Vol.75. P.169177.

Nygård H. 2011. Scavenging amphipods in the high Arctic Studies of benthic and sympagic amphipods in the genera Onisimus and Anonyx. A dissertation for the degree of Philosophiae Doctor. The University Centre in Svalbard, Department of Arctic Biology \& University of Tromsø. 29 p.

Okolodkov Yu.B. 1999. Species range types of recent marine dinoflagellates recorded from the Arctic // Grana. Vol.38. P.162-169.

Okutani T., Fujikura K., Kojima S. 1999. Two hadal bivalves of the family Thyasiridae from the plate convergent area of the Japan Trench // Venus. Vol.58. No.2. P.49-54.

Osborn K.J. 2009. Relationships within the Munnopsidae (Crustacea, Isopoda, Asellota) based on three genes // Zoologica Scripta. Vol.38. P.617-635.
Petrov N.B., Vladychenskaya I.P., Mironov A.N. 2012. Morphological and molecular analysis of phylogeny and phylogeography of the holasteroid deep-sea echinoids // Molecular Phylogenetics. Contributions of the $3^{\text {rd }}$ Moscow International Conference "Molecular Phylogenetics" (Molphy-3), July 31 - August 4, 2012. Moscow: Torus Press. P.62-63.

Petryashov V.V. 1993. [Deep-sea mysids (Crustacea: Mysidacea) of the Arctic basin (Arctic Ocean)] // Issledovania fauny morei [Explorations of the fauna of the seas]. Vol.45(53). P.70-89 [in Russian, English abstract].

Petryashov V.V. 2004. [Mysids (Crustacea, Mysidacea) of the Eurasiatic subbasin of the Arctic basin and the adjacent seas: the Barents, Kara and Laptev Seas] // Issledovania fauny morei [Explorations of the Fauna of the Seas]. Vol.54(62). P.124-145 [in Russian]

Raupach M.J, Mayer C., Malyutina M., Wägele J.-W. 2009. Multiple origins of deep-sea Asellota (Crustacea: Isopoda) from shallow waters revealed by molecular data // Proceedings of the Royal Society. B. Vol.276. P.799-808.

Richling I. 2000. Arktische Bivalvia - eine taxonomische Bearbeitung auf Grundlage des Materials der Expeditionen Transdrift 1 und ARK IX/4 (1993) in das Laptevmeer // Schriften zur Malakozoologie. Bd.15. S.1-93.

Riehl T., Brandt A. 2010. Descriptions of two new species in the genus Macrostylis Sars, 1864 (Isopoda, Asellota, Macrostylidae) from the Weddell Sea (Southern Ocean), with a synonymisation of the genus Desmostylis Brandt, 1992 with Macrostylis // ZooKeys. Vol.57. P.9-49.

Riehl T., Wilson G.D.F., Hessler R.R. 2012. New Macrostylidae Hansen, 1916 (Crustacea: Isopoda) from the Gay Head-Bermuda transect with special consideration of sexual dimorphism // Zootaxa. Vol.2783. P.1-20.

Rodríguez E., López-González P.J., Daly M. 2009. New family of sea anemones (Actiniaria, Acontiaria) from deep polar seas // Polar Biology. Vol.32. P.703-717.

Rogacheva A.V. 2007. Revision of the Arctic group of species of the family Elpidiidae (Elasipodida, Holothuroidea) // Marine Biology Research. Vol.3. No.6. P.367-396.

Rogacheva A.V. 2012. Taxonomy and distribution of the genus Kolga (Elpidiidae: Holothuroidea: Echinodermata) // Journal of the Marine Biological Association of the United Kingdom. Vol.92. No.5. P.11831193.

Rogacheva A.V., Mironov A.N., Minin K.V., Gebruk A.V. 2013. Morphological evidence of depth-related speciation in deep-sea Arctic echinoderms // Invertebrate Zoology. Vol.10. No.1. P.143-166.

Rosenberg G. 2009. Malacolog 4.1.1: A Database of Western Atlantic Marine Mollusca. [WWW database (version 4.1.1)] URL http://www.malacolog.org/.

Ryźycki O., Gruszcyńsky M. 1986. Macrofauna associated with laminarians in the coastal waters of West Spitsbergen // Polish Polar Research. Vol.7. No.4. P.337-351.

Sars G.O. 1886. Crustacea // Den Norske Nordhavs Expedition 1876-1878. Bd. 19-25. Zoologi. Crustacea. II. S.1-124. 
Segerstråle S.G. 1957b. On the immigration of the glacial relicts of Northern Europe, with remarks on their prehistory // Commentationes Biologicae. Societas Scientiarum Fennica. Vol.16(16). P.1-117.

Schmitt W.L., Kott P. 1969. Antarctic Ascidiacea // Antarctic Research Series. Vol.13. P.1-239.

Shchedrina Z.G. 1964. [Foraminifers (Foraminifera) from the high latitudes of the Arctic Basin] // Trudy Arktichskogo i Antarkticheskogo Nauchno-Issledovatelskogo Instituta [Proceedings of the Arctic and Antarctic Science Research Institute]. Vol.259. P. 79-119 [in Russian].

Shorygin A.A. 1928. [Die Echinodermen des Barentsmeeres] // Berichte des Wissenschaftlichen Meeresinstituts. Bd.3. No.4. S.1-128 [in Rissian, with German Summary].

Sirenko B.I. 2001 (ed.). List of species of free-living invertebtates of Eurasian Arctic seas and adjacent deep waters // Explorations of the fauna of the seas. Vol.51(59). P.1-131.

Sirenko B.I., Denisenko S., Deubel H., Rachor E. 2004. Deep water communities in the Laptev Sea and adjacent parts of Arctic Ocean // Exploration of the Fauna of the Seas. Vol.54(62). P.28-73.

Sirenko B.I., Petryashov V.V., Rachor E., Hinz K. 1995. Bottom biocoenoses of the Laptev Sea and adjacent areas // Berichte zur Polarforschung. Vol.176. P.211221.

Smirnov A.V. 1994. Arctic echinoderms: composition, distribution and history of the fauna // B. David, A. Guille, J.D. Feral, M. Roux (eds.). Echinoderms through time. Proceeding of the Eighth International Echinoderm Confefence, Dijon, France, 6-10 September 1993. Rotterdam: A.A. Balkema. P.135-142.

Smirnov A.V., Smirnov I.S. 2006. [New echinoderms findings in the Laptev Sea (1993-1998 expeditions)] // Issledovania fauni morei [Exploration of the Fauna of the Seas]. Vol.56(64). P.93-147 [in Russian, English abstract]

Sokolov V. 2000. Deep-sea shrimps of the genus Bythocaris G.O. Sars in the collections of Russian museums, with the description of a new species (Crustacea: Decapoda: Hippolytidae) // Zoologische Mededelingen Leiden. Vol.74. No.24. P.403-468.

Soltwedel T., Jaeckisch N., Ritter N., Hasemann C., Bergmann M., Klages M. 2009. Bathymetric patterns of megafaunal assemblages from the arctic deep-sea observatory HAUSGARTEN // Deep Sea Research Part I: Oceanographic Research Papers. Vol.56. No.10. P.1856-1872.

Stephensen K. 1923. Crustacea Malacostraca. V. Amphipoda, Part I // Danish Ingolf-Expedition. Vol.3. P.1-100.

Stephensen K. 1925. Crustacea Malacostraca. VI. Amphipoda, Part II // Danish Ingolf-Expedition. Vol.3. P.101-178.

Stephensen K. 1931. Crustacea Malacostraca. VII. Amphipoda, Part III // Danish lngolf-Expedition. Vol. 3. P.179-290.

Stephensen K. 1944. Crustacea. Malacostraca VIII. Amphipoda, Part IV // Danish Ingolf- Expedition. Vol.3d. P.1-51.
Stöhr S., O’Hara T. (eds.). 2012. World Ophiuroidea database. Accessed at http://www.marinespecies.org/ ophiuroidea on 2012-10-08.

Strauch F. 1972. Phylogenese, Adaptation und Migration einiger nordischer mariner Molluskengenera (Neptunea, Panomya, Cyrtodaria und Mya) // Abhandlungen der Senckenbergischen Naturforschenden Gesellschaft. Bd.531. S.1-211.

Svavarsson J., Stromberg J.-O., Brattergardt T. 1993. The deep-sea asellote (Isopoda, Crustacea) fauna of the Northern Seas: species composition, distributional patterns and origin// Journal of Biogeography. Vol.20. P.537-555.

Sverdrup H.U., Johnson M.W., Fleming R.H. 1942. The Oceans, Their Physics, Chemistry, and General Biology. New York: Prentice-Hall. 1087 p.

Tandberg A.H.S. 2011. Studies on the amphipod genus Metopa (Stenothoidae): taxonomy, ecology, phylogeny. A dissertation for the degree of Philosophiae Doctor. Tromsø: University of Tromsø. 48 p.

Tarasov N.E., Zevina G.B. 1957. [Cirripedia Thoracica of the Seas of the USSR] // Fauna SSSR [Fauna of USSR]. Is.69. Crustacea. Vol.6. No.1. P.1-268 [in Russian].

Thiel M., Gutow L. 2005. The ecology of the rafting marine environment. II. The rafting organisms and community // Oceanography and Marine Biology: An Annual Review. Vol.43. P.279-418.

Treshnikov A.F. (ed.). 1985. [Atlas of the Arctic]. Moscow: Main Department of geodesy and cartography of the Council of Ministers USSR. 204 p. [in Russian].

Tyler P.A., Young C.M. 1998.Temperature and pressure tolerances in dispersal stages of the genus Echinus (Echinodermata, Echinoidea): perquisites for deepsea invasion and speciation // Deep-Sea Research. Part II. Vol.45. No.1-3. P.253-277.

Vader W., Johnsen J.R., Berge J. 2005. Studies on the genus Onisimus Boeck, 1871 (Crustacea, Amphipoda, Lysianassoidea, Uristidae). Part I. The brevicaudatus and sextonae species groups // Organisms Diversity \& Evolution. Vol.5. No.2. P.161-164.

Vallet C., Dauvin J.C. 1995. Quantitative and qualitative composition of the suprabenthic amphipods from the English Channel // Polskie Archiwun Hidrobiologii. Vol.42. No.4. P.461-481.

Vinogradov G.M. 1999. Deep-sea near-bottom swarms of pelagic amphipods Themisto: observations from submersibles // Sarsia. Vol.84. P.465-467.

Vinogradov M.E., Volkov A.F., Semenova T.N. 1996. Hyperiid amphipods (Amphipoda, Hyperiidea) of the World Oceans. Lebanon, USA: Science Publisher inc. $632 \mathrm{p}$.

Vinogradova N.G. 1997. Zoogeography of the Abyssal and Hadal Zones // Advances in Marine Biology. Vol.32. P.325-387.

Weisshappel J. 2001. Distribution and diversitry of the hyperbenthic amphipod family Calliopiidae in the different seas around the Greenland-Iceland-FaeroeRidge // Sarsia. Vol.86. P.143-151.

Zenkevitch L. 1963. Biology of the seas of the U.S.S.R. London: George Allen \& Unwin LTD. 955 p.

Zezina O.N. 1980. [On a deep-sea find of brachiopods in the Arctic basin] // M.E. Vinogradov, I.A. Melnikov (eds.). [Biology of the Central Arctic Ocean]. Moscow: Nauka Press. P.240-241 [in Russian]. 